\title{
Sustained Arginase 1 Expression Modulates Pathological Tau Deposits in a Mouse Model of Tauopathy
}

\author{
Jerry B. Hunt Jr, ${ }^{1,2}$ Kevin R. Nash, ${ }^{1,3}$ Devon Placides, $, 1,2$ Peter Moran, ${ }^{1}$ Maj-Linda B. Selenica, ${ }^{1,2}$ Firas Abuqalbeen, ${ }^{1,2}$ \\ Kevin Ratnasamy, ${ }^{1,2}$ Nina Slouha, ${ }^{1,2}$ CSantiago Rodriguez-Ospina, ${ }^{1}$ Miloni Savlia, ${ }^{1}$ Yashobha Ranaweera, ${ }^{1,2}$ \\ Patrick Reid, ${ }^{1}$ Chad A. Dickey, Rodrigo Uricia, ${ }^{1,2}$ Clement G.Y. Yang, ${ }^{3}$ Leslie A. Sandusky, ${ }^{1,2}{ }^{-}$Marcia N. Gordon, ${ }^{1,3}$ \\ Dave Morgan, ${ }^{1,3}$ and Daniel C. Lee ${ }^{1,2}$ \\ ${ }^{1}$ Byrd Alzheimer's Institute, ${ }^{2}$ College of Pharmacy and Pharmaceutical Sciences, and ${ }^{3}$ Morsani College of Medicine, University of South Florida, Tampa, \\ Florida 33613
}

Tau accumulation remains one of the closest correlates of neuronal loss in Alzheimer's disease. In addition, tau associates with several other neurodegenerative diseases, collectively known as tauopathies, in which clinical phenotypes manifest as cognitive impairment, behavioral disturbances, and motor impairment. Polyamines act as bivalent regulators of cellular function and are involved in numerous biological processes. The regulation of the polyamines system can become dysfunctional during disease states. Arginase 1 (Arg1) and nitric oxide synthases compete for $\mathrm{L}$-arginine to produce either polyamines or nitric oxide, respectively. Herein, we show that overexpression of Arg1 using adeno-associated virus (AAV) in the CNS of rTg4510 tau transgenic mice significantly reduced phospho-tau species and tangle pathology. Sustained Arg1 overexpression decreased several kinases capable of phosphorylating tau, decreased inflammation, and modulated changes in the mammalian target of rapamycin and related proteins, suggesting activation of autophagy. Arg1 overexpression also mitigated hippocampal atrophy in tau transgenic mice. Conversely, conditional deletion of Arg1 in myeloid cells resulted in increased tau accumulation relative to Arg1-sufficient mice after transduction with a recombinant AAV-tau construct. These data suggest that Arg1 and the polyamine pathway may offer novel therapeutic targets for tauopathies.

Key words: arginase; autophagy; inflammation; kinase; polyamine; tau

\section{Introduction}

Tau is an abundant protein in the CNS and functions to promote microtubule assembly and stabilization in axons. Abnormal processing, posttranslational modifications of tau, and mutations in the MAPT gene induce accumulation, aggregation, redistribution, and toxicity to neurons. Although the toxicity between the various species of tau has been a target of debate, ultimately, the end product of tau dysregulation is neuronal demise. Tau pathology associates with $>20$ neurodegenerative diseases together known as tauopathies (Lee et al., 2001). Posttranslational modifications of tau occur through phosphorylation (Lee et al., 2004), glycosylation (Ledesma et al., 1994), o-GlcNAcylation (Arnold et al., 1996), acetylation (Cohen et al., 2011), oxidation (Landino et al.,

\footnotetext{
Received Sept. 23, 2014; revised Sept. 1, 2015; accepted Sept. 27, 2015

Author contributions: K.R.N., M.-L.B.S., L.A.S., M.N.G., D.M., and D.C.L. designed research; J.B.H., D.P., F.A., K.R., N.S., S.R.-O., M.S., Y.R., P.R., and C.G.Y.Y. performed research; C.A.D. contributed unpublished reagents/analytic tools; J.B.H., D.P., P.M., F.A., K.R., N.S., Y.R., P.R., R.U., and C.G.Y.Y. analyzed data; J.B.H. wrote the paper.

This work was supported by the Alzheimer's Association Mentored New Investigator Research Grant to Promote Diversity (MNIRDG). We thank Rakez Kayed for the gift of the anti-tau oligomer anti-body (T22) and Sidney Morris for the gift of the chicken anti-Arg1 antibody.

The authors declare no competing financial interests.

Correspondence should be addressed to Dr. Daniel C. Lee, Byrd Alzheimer's Institute, University of South Florida, 4001 E. Fletcher Ave, Tampa, FL 33613. E-mail: dlee1@health.usf.edu.

DOI:10.1523/JNEUROSCI.3959-14.2015

Copyright $\odot 2015$ the authors $\quad 0270-6474 / 15 / 3514842-19 \$ 15.00 / 0$
}

2004), isomerization (Miyasaka et al., 2005), sumoylation (Dorval and Fraser, 2006), ubiquitination (Cripps et al., 2006), nitration (Reynolds et al., 2006; Reyes et al., 2008; Reyes et al., 2011; Reyes et al., 2012), polyamination (Tucholski et al., 1999), and proteolytic cleavage (Mondragón-Rodríguez et al., 2008), which result in tau dysfunction. Inhibiting these modifications have been proposed as therapeutic targets in tauopathies including Alzheimer's disease (AD). In addition, inflammation has also been shown to modify tau pathology; however, the exact mechanisms that govern microglial activation and the by-products that affect tau biology remain less clear (Bhaskar et al., 2010; D.C. Lee et al., 2010; Ghosh et al., 2013; Nash et al., 2013).

Microglia survey the CNS, maintain neuronal integrity by synaptic pruning, phagocytose dying neurons, and coordinate immune signaling (Kettenmann et al., 2013; Miyamoto et al., 2013; Morris et al., 2013; Wake et al., 2013). However, by-products increased during microglial activation can regulate pathology associated with neurodegenerative disease. L-arginine metabolism dictates dichotomous outcomes: nitric oxide production or generation of polyamines. Arginase 1 (Arg1) or Arginase 2 (Arg2) metabolize L-arginine to generate ornithine (and subsequent polyamines), whereas nitric oxide synthases (NOS), including inducible NOS (iNOS), endothelial NOS, and neuronal NOS, metabolize L-arginine to 

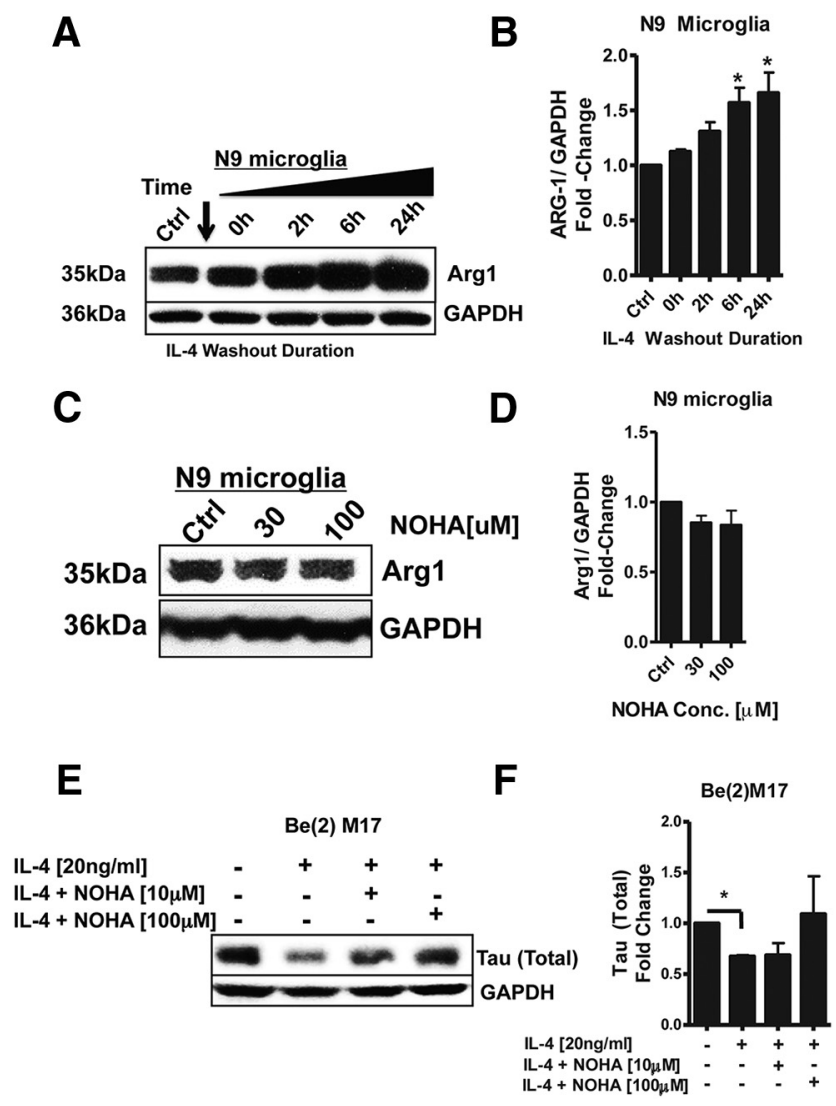

Figure 1. Alternative activation of $\mathrm{N} 9$ microglia reduces tau levels in vitro. $\boldsymbol{A}, \mathrm{N} 9$ microglia were treated with IL-4 $(20 \mathrm{ng} / \mathrm{ml})$ for $4 \mathrm{~h}$. Cells were washed, incubated with serum-free medium, and harvested at $0,2,6$, and $24 \mathrm{~h}$. Arg1 progressively increased at 6 and $24 \mathrm{~h}$. B, Graph depicting the fold change in Arg1 quantitation after IL-4 treatment from A. C, The Arg1 inhibitor NOHA did not reduce Arg1 expression levels. D, Graph depicting the fold change in Arg1 expression after NOHA treatment from $\boldsymbol{B}$. $\boldsymbol{E}$, N9 microglia were treated with IL-4 or vehicle for $4 \mathrm{~h}$, washed, and then cocultured with Be(2)M17 cells for $24 \mathrm{~h}$ with and without NOHA. Western blot shows that tau decreased in M17 cells when cocultured with $\mathrm{N} 9$ cells previously activated with IL-4 and this effect was prevented by NOHA treatment. $\boldsymbol{F}$, Graph depicting the fold change in tau quantitation of M17 cells after coculture with IL4-treated N9 cells from $\boldsymbol{E}$. Statistical analyses were performed using one-way ANOVA, followed by Fisher's PLSD multiple-comparison tests. ${ }^{*} p<0.05, n=3$ independent experiments.

generate nitric oxide, which drives nitration of $\mathrm{A} \beta$ and enhances aggregation and plaque formation (Kummer et al., 2011). Conversely, in $A \beta$-depositing transgenic mice devoid of iNOS, exaggerated AD-like pathology suggests that a critical balance between Arg 1 and NOS determines the acceleration vs mitigation of amyloid deposition (Colton et al., 2006). Nitration of tau has also been observed during tauopathies and other aggregation-prone proteins such as $\alpha$-synuclein are also nitrated (Reynolds et al., 2006; Reyes et al., 2008; Yu et al., 2010; Reyes et al., 2011; Reyes et al., 2012).

The present study aimed to identify the role of Arg1 overexpression using recombinant adeno-associated virus (rAAV) in a mouse model of forebrain tauopathy (rTg4510 tau mice). We hypothesized that shifting $\mathrm{L}$-arginine metabolism to favor the polyamine pathway would curtail tau pathology. Results identify that persistent exposure of Arg1 in the hippocampus of rTg4510 tau transgenic mice leads to reduced tau burden, decreased inflammation, and increased activation of autophagy. Moreover, considering the impact of L-arginine metabolism during inflammation, our results suggest that therapeutics that increase arginase expression and/or agents that positively regulate polyamine levels may serve as new therapeutic targets for tauopathies.

\section{Materials and Methods}

Virus production. rAAV9 expressing Arg1 (GI:158966684) was cloned using PCR from mouse brain cDNA and the following primers: GAGAC CGGTCCACCATGAGCTCCAAGCCAAAGTCCTTAG and CTCGCT AGCTCACATGGCATAGTCAGGCACGTCATAAGGATAGCTAGAAG CCATCTTAGgTGgTTTAagGTAGTCAGTCCC. Arg1 was cloned into the pTR2-MCS vector at the Age I and NheI cloning sites. This vector contains the AAV2 terminal repeats and the hybrid cytomegalovirus (CMV)-chicken $\beta$-actin promoter for Arg1 mRNA transcription. A hemagglutinin (HA)-tag was added to the $\mathrm{C}$ terminus of $\mathrm{Arg} 1$ for protein detection. C-terminal truncated human Tau (aa 1-421) was a kind gift from Dr. Lester Binder. Tau was cloned into the pTR2-MCS vector with an HA tag appended to the $\mathrm{N}$ terminus for detection of the protein expression. Recombinant AAV9 vectors were generated and purified as described previously (Carty et al., 2013). rAAV particle concentrations are expressed as vector genomes $/ \mathrm{ml}(\mathrm{vg} / \mathrm{ml})$. Vector genomes were quantitated using a modified version of the dot plot protocol described previously (Nash et al., 2013). UF11 plasmid was used to generate rAAV9-green fluorescent protein (GFP) virus as described previously (Carty et al., 2013).

Cell culture experiments. N9 microglia were used as a model of murine CNS microglial activation and a good source of Arg1 expression and induction. Be(2)M17 cells (human neuroblastoma) and C3 HeLa cells, which stably overexpress wild-type 4R0N human tau, were used as a model for tau biology. All cells were maintained in $75 \mathrm{~cm}^{2}$ flasks at $37^{\circ} \mathrm{C}$ in a $5 \% \mathrm{CO}_{2}$ humidified chamber in OPTIMEM containing $10 \%$ fetal bovine serum, $100 \mathrm{U} / \mathrm{ml}$ penicillin and $100 \mu \mathrm{g} / \mathrm{ml}$ streptomycin. In Experiment 1, N9 microglia cells were plated in 6-well dishes and treated with IL-4 (20 ng/ml; Life Technologies) for $4 \mathrm{~h}$, washed 3 times with PBS, and harvested for Arg1 expression measurement immediately $(0 \mathrm{~h})$ or after 2,6 , and $24 \mathrm{~h}$. N9 cells were also treated with the Argl inhibitor $N$ - $\omega$-hydroxy-L-norarginine (NOHA) for $24 \mathrm{~h}$. In Experiment 2, N9 microglia (top wells) were cocultured in 6-well insert Transwell Costar plates $(0.4 \mu \mathrm{m}$ membrane insert dishes; Corning), treated with IL-4 (20 ng/ml) for $4 \mathrm{~h}$, washed with 3 times in PBS, transferred to a separate 6-well dish with Be (2) M17 cells (bottom wells), and allowed to coincubate for $24 \mathrm{~h}$ with or without NOHA. In Experiment 3, the amino acid L-arginine (SigmaAldrich) was incubated with C3 HeLa cells for $72 \mathrm{~h}$ at various concentrations $(0-10 \mathrm{~mm})$. In Experiment $4,2 \mu \mathrm{g}$ of plasmid DNA of pTR2-MCS (plasmid vector) or pTR2-Arg1 was transiently transfected for $72 \mathrm{~h}$ with Lipofectamine 2000 (Life Technologies) following the manufacturer's protocols. Arginase activity was measured using a commercially available kit according to manufacturer's protocol (Sigma-Aldrich).

Transgenic mice. Overall experimental group assignments were balanced for genotype, genders, and litters. $\operatorname{rTg} 4510$ mice $(n=16,11$ male/5 female) were used in this experiment (Santacruz et al., 2005). These mice carry a transgene encoding the human tau P301L mutation under control of the tetracycline response element, as well as a transgene encoding the tetracycline-controlled transactivator protein regulated by the calcium-calmodulin kinase 2 (CamK2a) promoter. As controls, transgenic mice harboring the tet transactivator protein alone, and nontransgenic littermates $(n=7,4$ male/3 female) were used in this experiment.

Conditional cre-recombinase Arg1 knock-out were purchased from Jackson Laboratories (El Kasmi et al., 2008). Arg1 conditional knock-out allele comprised LoxP-flanked (floxed) Arg1 denoted as $\left(\right.$ Argl $\left.1^{\mathrm{fl} / \mathrm{fl}}\right)$ were mated with the "deleter" strain (Lyz2 ${ }^{\mathrm{tm} \text { (cre) }}$; LysMcre promoter) to produce Arg1 deficiency in myeloid cells. Genotypes used in the study consisted of Arg1-sufficient $\left(\operatorname{Arg} 1^{+/+}\right)$mice $(n=$ 13, 5 male/6 female) and (Arg1 fl/fl $/$ LysMcre $)$ mice $(n=9,5$ male/4 female).

Stereotaxic surgery. Study animals (rTg4510 mice) were given water and food ad libitum and maintained on the $12 \mathrm{~h}$ light/dark cycle and standard vivarium conditions. A $2 \mu \mathrm{l}$ volume of rAAV particles con- 
A

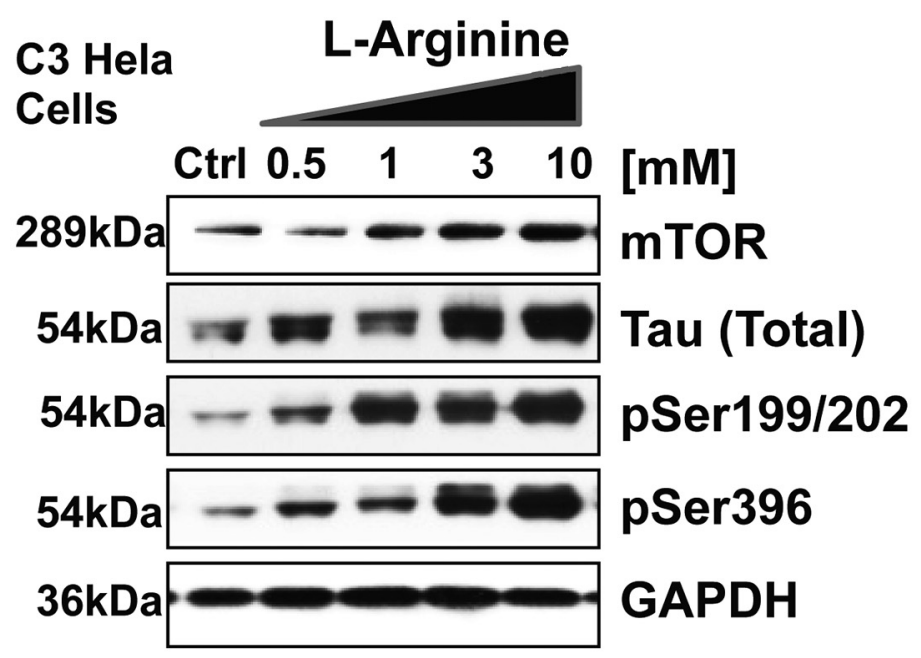

C

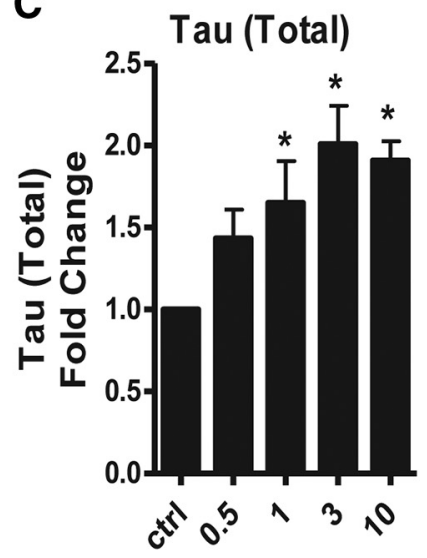

\section{L-Arginine [mM]}

D
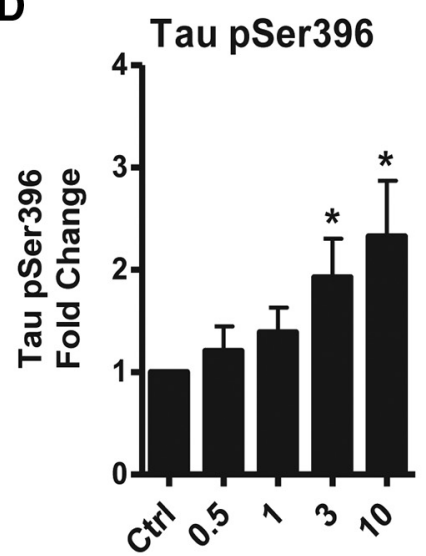

L-Arginine [mM]
B

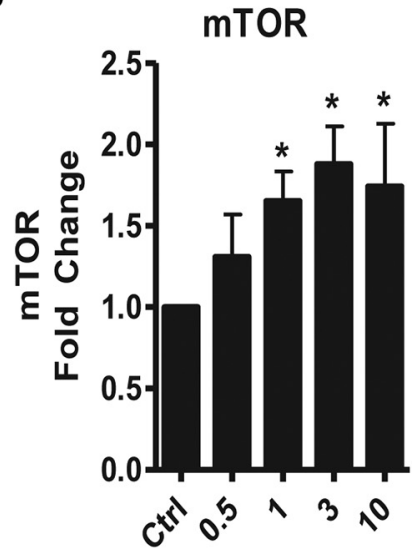

L-Arginine [mM]

E

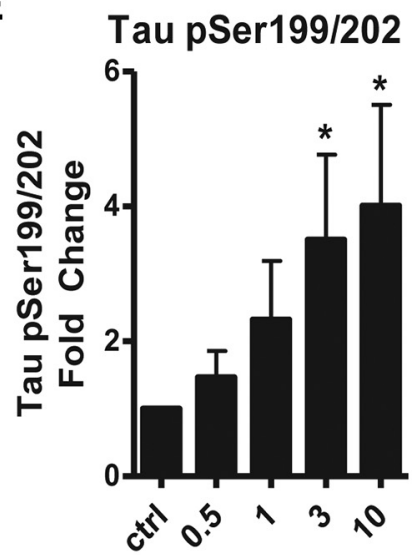

L-Arginine [mM]

Figure 2. L-arginine administration increases tau levels. L-Arginine [0-10 mu] was added to C3-Tau HeLa cells for $72 \mathrm{~h}$. A, Western blot for mTOR and tau after treatment with L-arginine. After quantitation, mTOR $(\boldsymbol{B})$, total tau $\left(\boldsymbol{C}\right.$ ), phospho-tau Ser396 (D), and phospho-tau Ser199/202 (E) progressively increased after L-arginine administration. $\left({ }^{*} p<0.05\right.$, mean \pm SEM, $n=3$ independent experiments).

taining UF11 (rAAV9-GFP) virus $\left(4 \times 10^{12} \mathrm{vg} / \mathrm{ml}\right)$ or Arg1 (rAAV9Arg1) virus $\left(4 \times 10^{12} \mathrm{vg} / \mathrm{ml}\right)$ was stereotaxically injected into the right dentate gyrus of the hippocampus of 4-month-old rTg4510 mice. Stereotaxic coordinates from bregma were $-2.7 \mathrm{~mm}$ anteroposterior, $-2.7 \mathrm{~mm}$ lateral, and $-3.0 \mathrm{~mm}$ ventral. The virus was administered using convection-enhanced delivery at a constant rate of $2.5 \mu \mathrm{l} / \mathrm{min}$ (Carty et al., 2013). Four months after injection, mice were weighed, anesthetized with barbiturates, and transcardially perfused with $25 \mathrm{ml}$ of $0.9 \%$ saline. One hemisphere of the brain was dissected, frozen, and stored at $-80^{\circ} \mathrm{C}$ for biochemical analysis; the opposite hemisphere was fixed in $4 \%$ paraformaldehyde in $100 \mathrm{~mm}$ phosphate buffer, $\mathrm{pH} 7.4$, for $24 \mathrm{~h}$. The tissue was cryoprotected by sequential immersion in $10 \%, 20 \%$, and $30 \%$ sucrose solutions. Brains were sectioned at $25 \mu \mathrm{m}$ using a sliding microtome. Every eighth section was collected at $50 \mu \mathrm{m}$ thickness. Sections were stored until staining at $4^{\circ} \mathrm{C}$ in Dulbecco's PBS containing $100 \mathrm{~mm}$ sodium azide.

In addition, both Arg1-sufficient/wild-type $\left(\operatorname{Arg} 1^{+/+}\right)$mice and myeloid-null $\operatorname{Arg} 1^{\mathrm{fl} / \mathrm{fl} /} / \mathrm{LysMcre}$ mice received an intrahippocampal (dentate gyrus) injection of the C-terminal truncated tau (truncated at 421) construct (rAAV-Tau-CT). Four months after injection, brains were processed as described above. Other Arg1-sufficient/ wild-type $\left(\operatorname{Arg} 1^{+/+}\right)$mice and myeloid-null $\operatorname{Arg} 1^{\mathrm{fl} / \mathrm{fl}} / \mathrm{L} y s M c r e$ mice received a stereotaxic intrahippocampal (dentate gyrus) unilateral injection of LPS ( $4 \mu \mathrm{g}$ in $2 \mu \mathrm{l}$; Salmonella abortus equii; Sigma-
Aldrich) and were killed 3 d later as described above. Tissue was harvested for either immunohistochemistry or RNA quantitation.

Immunohistochemistry and staining. Immunohistochemistry was performed on free-floating sections. Eight sections $200 \mu \mathrm{m}$ apart covering the site of injection were used for staining and analysis as described previously (Gordon et al., 2002). Sections were quenched for endogenous peroxidase with $10 \%$ methanol, $10 \% \mathrm{H}_{2} \mathrm{O}_{2}$, permeabilized $(0.2 \%$ lysine, $1 \%$ Triton X-100 in PBS), and incubated with various primary antibodies: rabbit anti-Tau (H-150; Santa Cruz Biotechnology); rabbit anti-Tau phosphorylated at Ser 199/202 (AnaSpec); rabbit anti-tau phosphorylated at Ser396 (AnaSpec); chicken anti-GFP (Abcam); chicken anti-rat Arg1 (generous gift from Dr. Sydney M. Morris, University of Pittsburg School of Medicine); p62/sqstm1 (ProteinTech); rat antimouse CD45, rat anti-mouse CD68, and rat anti-mouse CD11b (AbD Serotec); rabbit anti-IBA-1 (Wako Chemicals); rat anti-HA clone 3F10 (Roche); rabbit anti-YM1 (StemCell Technologies); and biotinylated anti-tau (AT8; Thermo Scientific) overnight at $4^{\circ} \mathrm{C}$. Sections were incubated in the appropriate biotinylated secondary antibody (Vector Laboratories) for $2 \mathrm{~h}$ if needed, followed by a $1 \mathrm{~h}$ incubation in Vectastain Elite $\mathrm{ABC}$ kit (Vector Laboratories) for enzyme conjugation. Color development was performed using $0.05 \%$ 3, 3' -diaminobenzidine (DAB; SigmaAldrich) enhanced with $0.5 \%$ nickelous ammonium sulfate (Thermo Scientific). During each immunohistochemical assay, the primary antibody was omitted for duplicate sections to evaluate nonspecific reactions of secondary antibodies. All sections for the immunohistochemical stains 


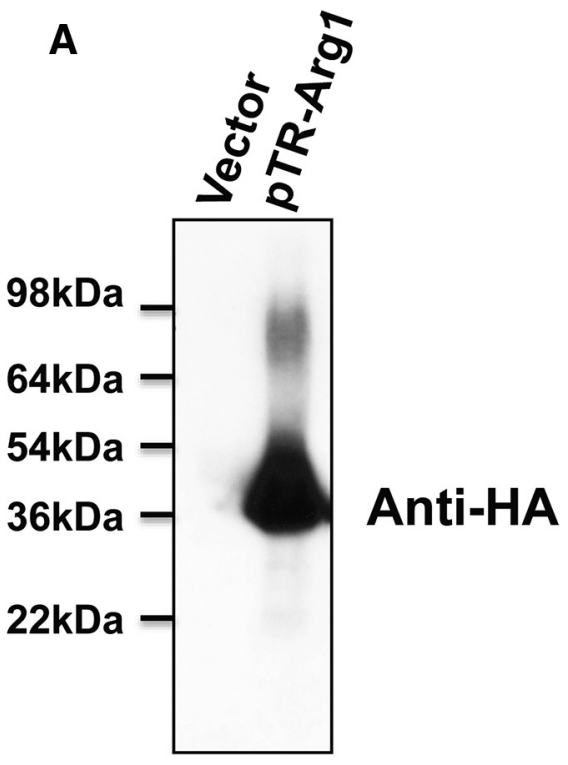

B

Arginase Activity

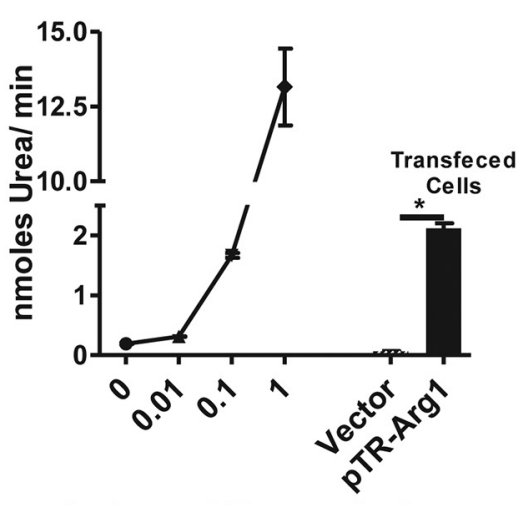

Arginase-1 Enzyme [ug]
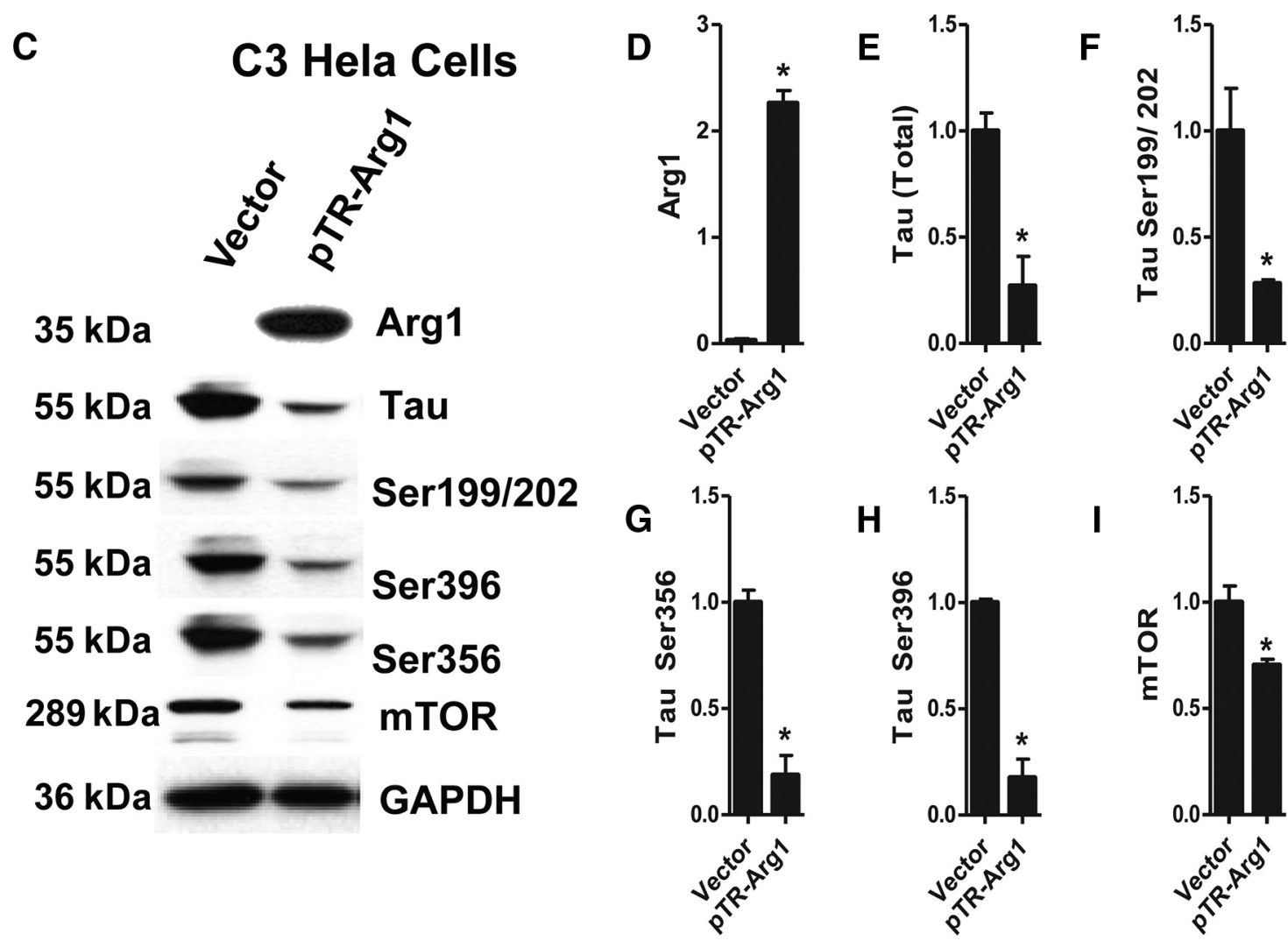

Figure 3. Arg1 overexpression in C 3 HeLa cells reduces tau. Arg1 was cloned with a fusion HA tag and arginase enzyme activity was measured. Western blot using anti-HA antibody shows the recombinant Arg1 expression after transfection $(\boldsymbol{A})$. Adding increasing amounts of purified arginase to the enzyme assay resulted in more product formation. Two micrograms of plasmid DNA transfected in cells produced $\sim 2 \mathrm{nmoles}$ of urea/min. This corresponded to the activity of $\sim 0.2 \mu \mathrm{g}$ of purified liver $\operatorname{Arg} 1(\boldsymbol{B})$. Western blot of tau molecular variants and $\mathrm{mTOR}$ levels after over expression of $\operatorname{Arg} 1$ ( ( ). Arg1 overexpression (D) in C3 HeLa cells caused a reduction in total tau (E), phospho tau Ser 199/202 (F), Ser356 (G), Ser396 (H), and mTOR (I) compared with cells transfected with empty vector (Vector). Statistical analyses were performed using one-way ANOVA with Fisher's PLSD multiple-comparison tests. ${ }^{*} p<0.05, n=4$ independent experiments.

were analyzed together and were processed at the same time under the same conditions.

For silver staining, a series of sections were mounted on glass slides and then stained using the Gallyas silver stain method as described previously (D.C. Lee et al., 2010). Briefly, slides were dipped in a solution containing $5 \%$ periodic acid for $5 \mathrm{~min}$, washed with water, and then incubated in a developer solution containing silver iodide, $0.5 \%$ acetic acid, $2.5 \%$ sodium carbonate, $0.1 \%$ ammonium nitrate,
$0.1 \%$ silver nitrate, $1 \%$ tungstosilic acid, and $0.7 \%$ formaldehyde. To stop reactions, slides were incubated in $0.5 \%$ acetic acid and then treated with $0.1 \%$ gold chloride, placed in $1 \%$ sodium thiosulfate, and washed in water. Slides were dehydrated and secured in DPX mounting medium with a coverslip. For stereology measurements, $50-\mu \mathrm{m}$-thick sections spaced every 300 $\mu \mathrm{m}$ were Nissl stained using cresyl violet.

Biochemical analysis/Western blotting. Dissected hippocampal tissue was used for Western blot analysis. Briefly, tissue was weighed and resus- 
pended in RIPA buffer (50 mm Tris pH7.6, 140 $\mathrm{mm} \mathrm{NaCl}, 1 \% \mathrm{NP} 40,0.5 \% \mathrm{Na}$ deoxycholate, $0.1 \%$ SDS) with a protease inhibitor mixture (Sigma-Aldrich) and phosphatase inhibitor mixtures I and II (Sigma-Aldrich) at $10 \mathrm{vol} / \mathrm{wt}$ of tissue. Tissue was homogenized with a tissue homogenizer and centrifuged at $40,000 \times g$ for $30 \mathrm{~min}$ at $4^{\circ} \mathrm{C}$. The detergent-soluble fraction (S1) was subjected to Western blot analysis. The pellet (P1) was resuspended in $70 \%$ formic acid $(2 \mu \mathrm{l} / \mathrm{mg}$ tissue $)$ and incubated for $30 \mathrm{~min}$ at room temperature. An equal volume of $1 \mathrm{M}$ Tris, $\mathrm{pH}$ 7.5, was added to the pellets and $\mathrm{NaOH}$ was added to a final $\mathrm{pH}$ of 7.5. Protein concentration was determined with the Pierce BCA protein assay. For Western blot analysis, protein was loaded onto a $4-20 \%$ gradient gel (20- to 26-well Midi SureLock System; Life Technologies). All groups $(n=8)$ were subjected to the same gel (resolving, transfer, analysis, and exposure) for a given target. Representative bands $(n=5-8)$ for each group were cropped for space considerations for figures. One microgram of total protein was loaded to measure tau epitopes including tau total (H150; SantaCruz Technology), tau ser199/202, ser262, ser356, ser396, (AnaSpec), AT8, AT180, AT270 (Thermo Scientific), and tau nY18 (Covance). Twenty to $30 \mu \mathrm{g}$ of total protein was loaded for cell culture experiments and for various proteins from mouse hippocampal tissue, including mammalian target of rapamycin (mTOR), phospho-mTOR ser2481, phospho-mTORser2448, g $\beta$ L, raptor, rictor, p38 MAPK (Cell Signaling Technology); casein kinase 2 (Abcam); GSK3 $\alpha 216 / \beta 279$ (Abcam); GAPDH (Meridian); p62/sqstm1 (ProteinTech); Arg1 (Abcam) or chicken antirat Arg1 (gifted by Dr. Sydney M. Morris, University of Pittsburg School of Medicine); and rat-anti-HA clone 3F10 (HA) (Roche). For tissue samples using formic acid extraction, the amount of protein loaded was based on the BCA of the crude extract.

For dot blot analysis, $1 \mu \mathrm{g}$ of total protein from whole-cell homogenates was spotted onto wet nitrocellulose membrane and allowed to air dry. Membranes were washed with Trisbuffered saline (20 mu Tris, $0.8 \% \mathrm{NaCl}, \mathrm{pH} 7.4$, with $0.006 \%$ Tween 20 ; TBST) and blocked with Blocker Blotto in TBS (Life Technologies) for $1 \mathrm{~h}$, washed 3 times for $10 \mathrm{~min}$ in TBST, and allowed to incubate with the primary antibody, anti-tau oligomeric antibody T22 (Blair et al., 2013; Sengupta et al., 2015) or the oligomerspecific antibody A11 (Shin et al., 2008) for 1-2 h, followed by $310 \mathrm{~min}$ washes. An HRPconjugated secondary antibody was allowed to incubate for $1 \mathrm{~h}$ and developed using chemiluminescence for detection of signal (Lumigold; SignaGen Laboratories).

Multiplex inflammation and cytokine analysis. Dissected hippocampal tissue was analyzed for cytokine and immunomodulating agents using multiplex bioassay. Tissue was weighed and processed in RIPA buffer (50 mm Tris, pH 7.6, $140 \mathrm{~mm} \mathrm{NaCl}, 1 \% \mathrm{NP} 40$, $0.5 \% \mathrm{Na}$ deoxycholate, $0.1 \%$ SDS) with protease inhibitor mixture (Sigma-Aldrich) and phosphatase inhibitor mixtures I and II (SigmaAldrich) at $10 \mathrm{vol} / \mathrm{wt}$ of tissue. Tissue was homogenized with a tissue homogenizer and centrifuged at $40,000 \times g$ for $30 \mathrm{~min}$ at $4^{\circ} \mathrm{C}$. Superna-

\section{Experimental design}

AAV9-ARG1/ AAV9-GFP

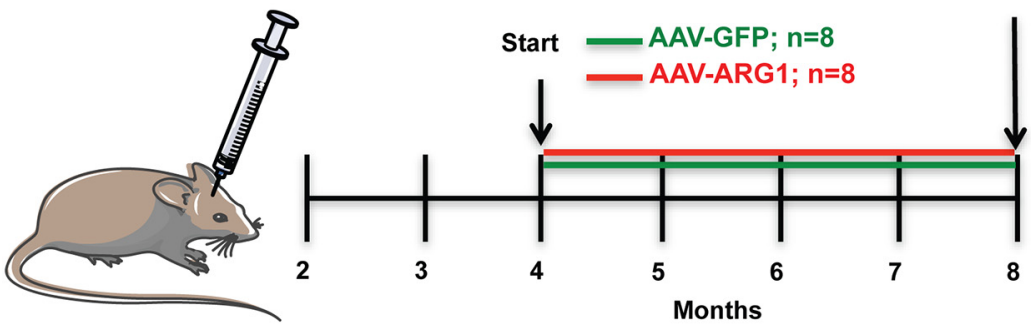

rTg4510 Mice

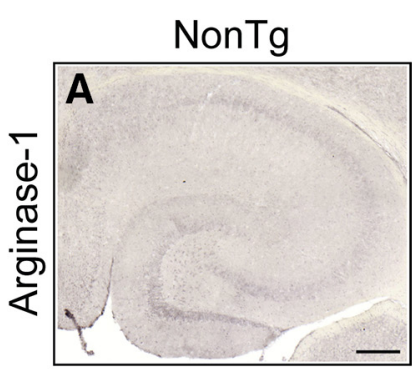

AAV9-GFP
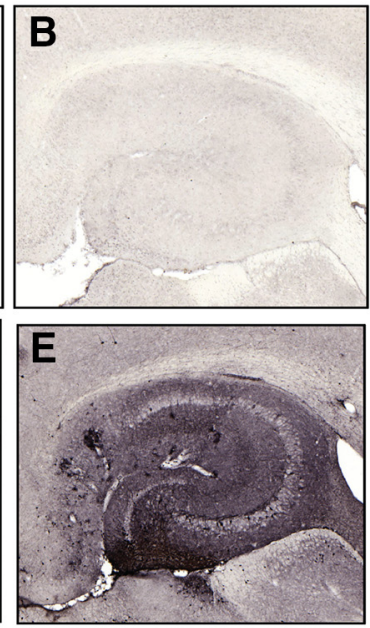

AAV9-ARG1
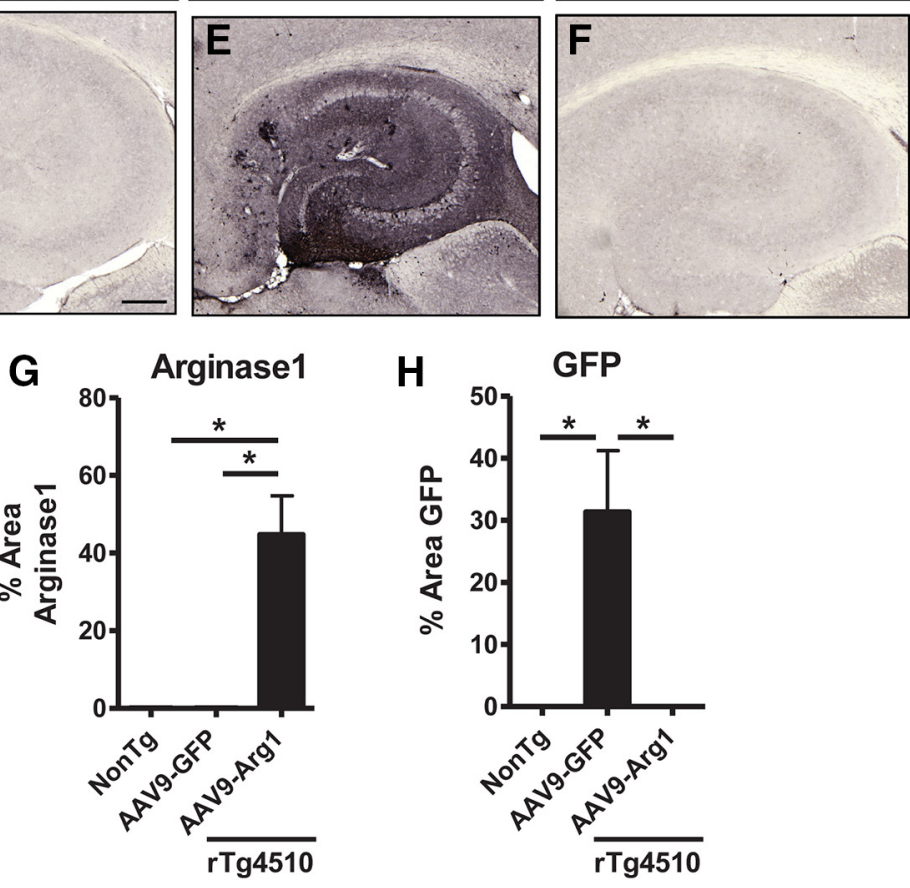

GFP

H

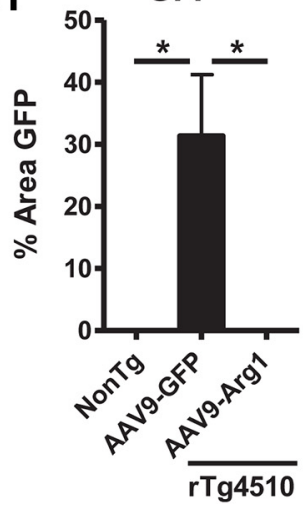

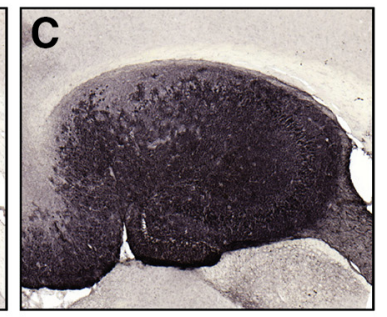

Figure 4. rAAV-mediated Arg1 and GFP delivery to the mouse hippocampus. Four-month-old rTg4510 tau transgenic mice received stereotaxic injection of either rAAV-Arg1 or rAAV-GFP in the hippocampus (HPC) with a viral incubation time of 4 months. The experimental design is depicted. Shown is immunohistochemical staining for $\operatorname{Arg} 1(\operatorname{Arg} 1 ; \boldsymbol{A}-\boldsymbol{C})$ and $(\mathrm{GFP} ; \boldsymbol{D}-\boldsymbol{F})$ in nontransgenic mice $(\boldsymbol{A}, \boldsymbol{D})$, rTg4510 tau transgenic mice injected with rAAV-GFP $(\boldsymbol{B}, \boldsymbol{E})$, or rTg4510 transgenic mice injected with rAAV-Arg1 $(\boldsymbol{C}, \boldsymbol{F})$. $\boldsymbol{A}$-C, Anti-Arg1 staining. Arg1 expression was observed throughout the hippocampus in mice that received $\mathrm{rAAV}$-Arg1, but not in mice that received rAAV-GFP. D-F, anti-GFP staining. GFP was observed after rAAV-GFP injection, but not after rAAV-Arg1 injection. Percent area of immunohistochemical staining for $\operatorname{Arg} 1(\boldsymbol{G})$ and GFP $(\boldsymbol{H})$ were quantified by image analysis. Statistical analyses: ANOVA with Fisher's multiple-comparison test, ${ }^{*} p<0.05 ; n=8$.

tant samples were load onto the multiplex Mouse TH1/TH2 9-Plex Ultra-Sensitive platform Kit (catalog \#K15013C-1; Meso Scale Discovery) according to the manufacturer's protocol.

L-arginine determination (ELISA). The L-arginine concentration in brain homogenates (30 $\mu \mathrm{g}$ of total protein) was measured according to the manufacturer's instructions using the mouse L-arginine ELISA Kit (catalog \#MBS2600680; MyBioSource). L-Arginine standards were pre- 
A

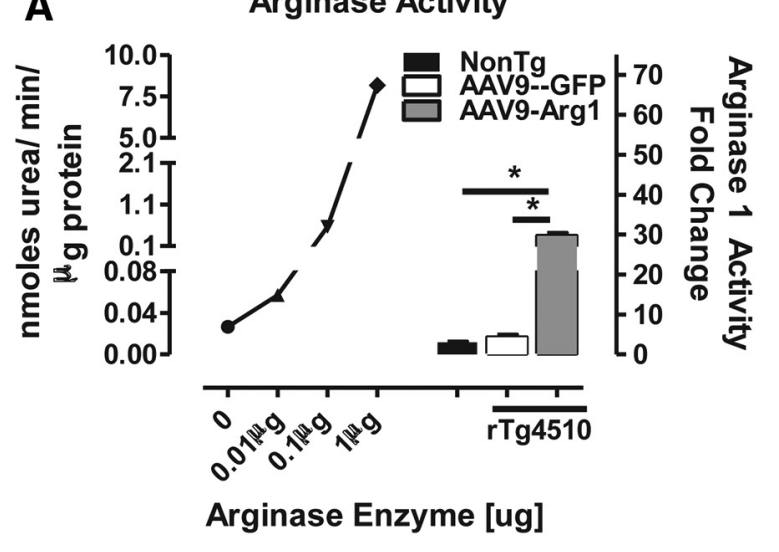

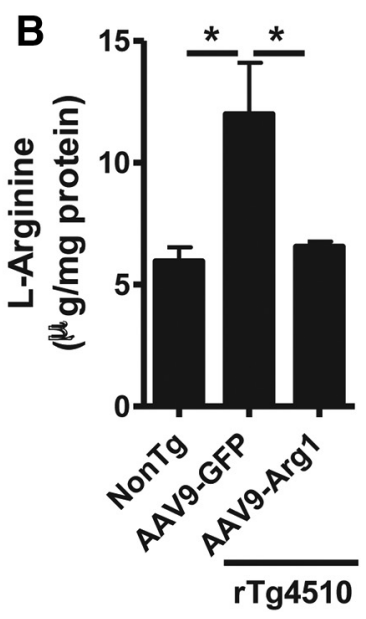

curve was generated from a pool of naive mice and experimental groups spanning three logs of a dynamic range. Sixty nanograms from each mouse was used to generate cDNA using Superscript III First Strand Synthesis System (Life Technologies). Quantitect primer assays target gene primers were used (Lys2: QT01555701, Arg1:QT00134288; Qiagen) with SYBR-green-based real-time qRT-PCR (Sigma-Aldrich). The PCR included: 1 cycle of $95^{\circ} \mathrm{C} / 5 \mathrm{~min}, 95^{\circ} \mathrm{C} / 30 \mathrm{~s}$, and $60^{\circ} \mathrm{C} / 1 \mathrm{~min}$, followed by 40 amplification cycles of $95^{\circ} \mathrm{C} / 30 \mathrm{~s}$. Primers were validated after each cycle by performing a melt curve analysis. The Opticon 2 TM Real Time PCR System (Version 4.3; BioRad) was used to detect the amplicon.

Image analysis. Tissue sections from mice were digitized with a Zeiss Mirax-scan 150 slide scanner. Immunohistochemical staining and Gallyas Silver positive stain was analyzed using Zeiss Neurocyte IAE image software (created by Andrew Lesniak). The hippocampus was analyzed for tau-positive neurons and was segmented using hue, saturation, and value color discrimination. Segmentation thresholds were established with images with high and low levels of positive staining to confirm positive staining over background levels. This range was held constant for analysis of every section (Gordon et al., 2002). Data were obtained as pared according to assay specifications to generate the standard curve. Briefly, a polyclonal biotinylated mouse L-arginine antibody (provided) was used at 1:100, along with the enzyme-conjugate diluent. The 96-well plates were washed manually with $350 \mu$ l of wash solution per well. Next, $10 \mu \mathrm{g}$ of solubilized protein from each sample was used per well. The precoated plate with samples and standards was incubated at $37^{\circ} \mathrm{C}$ for 90 $\mathrm{min}$. The plate was washed 3 times and then incubated with the biotinylated mouse L-arginine antibody $(1: 100)$ for $60 \mathrm{~min}$ at $37^{\circ} \mathrm{C}$. The plate was subsequently washed three times then incubated with the enzymeconjugate solution for $30 \mathrm{~min}$ at $37^{\circ} \mathrm{C}$. The plate was then washed five times and incubated for $20 \mathrm{~min}$ with the color-developing reagent at $37^{\circ} \mathrm{C}$. A stopping solution was then added and the plate was read at 450 $\mathrm{nm}$.

Arginase activity assay. Arginase activity was determined by previous methods with slight modifications. Briefly, dissected hippocampal tissue was lysed, weighed, and processed in RIPA buffer (50 mM Tris, $\mathrm{pH} 7.6$, $140 \mathrm{~mm} \mathrm{NaCl}, 1 \% \mathrm{NP} 40,0.5 \% \mathrm{Na}$ deoxycholate, $0.1 \%$ SDS) with protease inhibitor mixtures (Sigma-Aldrich) and phosphatase inhibitor mixtures I and II (Sigma-Aldrich) at $10 \mathrm{vol} / \mathrm{wt}$ of tissue. Tissue was homogenized with a tissue homogenizer and centrifuged at 40,000 $\times g$ for $30 \mathrm{~min}$ at $4^{\circ} \mathrm{C}$. Supernatant fractions $(10 \mu \mathrm{g}$ of total protein in $25 \mu \mathrm{l})$ were incubated at $45^{\circ} \mathrm{C}$ with $50 \mu \mathrm{l}$ of a $10 \mathrm{~mm} \mathrm{MnCl}_{2}$ in $50 \mathrm{~mm}$ Tris, $\mathrm{pH}$ 7.4, to activate the enzyme. Twenty-five microliters of a L-Arginine $(0.5 \mathrm{M}$ stock solution) (Sigma-Aldrich) was added to samples and incubated at $37^{\circ} \mathrm{C}$ for $2 \mathrm{~h}$. The reaction was stopped by adding $400 \mu \mathrm{l}$ of $\mathrm{H}_{2} \mathrm{SO}_{4}$ : $\mathrm{H}_{3} \mathrm{PO}_{4}: \mathrm{H}_{2} \mathrm{O}$ (1:3:7), followed by $25 \mu$ lof $\alpha$-isonitrosopropione ( $9 \% \mathrm{w} / \mathrm{v}$; Sigma-Aldrich). The reaction was incubated at $100^{\circ} \mathrm{C}$ for $45 \mathrm{~min}$ and protected from light. Aliquots were subjected to a 96 -well plate and analyzed with a spectrophotometer at $540 \mathrm{~nm}$. Various standards for urea (ICN Biochemicals) in the same buffers were used to determine arginase enzyme reaction product. In addition, pure arginase liver enzyme (146 units/mg solid; 200 units/mg protein) was used to verify assay conditions and determine the relative amount of arginase activity in brain samples compared with pure arginase enzyme ( 1 unit will convert $1 \mu \mathrm{mol}$ of $\mathrm{L}$-arginine to ornithine and urea in $1 \mathrm{~min}$ at $37^{\circ} \mathrm{C}, \mathrm{pH} 9.5$ ).

qRT-PCR. qRT-PCR was performed on hippocampal brain tissue of various conditional LoxP Arg1 knock-out mice and LysMcre knock-in mice for Arg1 and lysozyme 2 as described in detailed previously (Lee et al., 2013b). Briefly, total RNA from each mouse was used for qRT-PCR and extracted using Qiagen's All Prep DNA/RNA/Protein kit. A standard

the percent area of the positively stained immunochemical image. All values (eight sections) obtained from a single mouse were then averaged to represent a single value for each brain region.

Stereologer software (Stereology Resource Center), together with a Leica DM4000B microscopre and a Prior Optiscan II stage, were used for neuronal stereological counts and hippocampal volume. Nissl-stained tissue was used for these analyses.

Statistics. For each dependent variable, statistical analysis was performed using Student's $t$ test or one-way ANOVA, followed by Fisher's LSD post hoc means comparison test with $p$-values of $<0.05$ considered significant using StatView software version 5.0 (SAS Institute). Graphs were generated using GraphPad Prism version 5.0 software.

\section{Results}

Increased $\mathrm{L}$-arginine metabolism modifies tau levels in vitro L-Arginine and its metabolism represent a critical branch point during inflammation. Proinflammatory stimuli or putative M1 activation promote iNOS and can generate nitric oxide. Conversely, alternative activation or putative M2 stimuli (typically induced with IL-4/IL-13) promote Arg1 and polyamine formation. By-products of NOSs can nitrate tau at Tyr18, Tyr29, Tyr197, and Tyr395 (Wang et al., 2014). However the role of Arg1 on tau biology and neurodegenerative diseases has not been fully investigated. To determine the extent to which IL-4 exposure temporally increases Arg1 expression, N9 microglia cells were treated with IL-4 for $4 \mathrm{~h}$, washed, and harvested at various time points (Fig. 1A). N9 cells exposed to IL-4 showed a progressive increase in Arg1 expression up to $24 \mathrm{~h}$ (Fig. $1 A, B$ ). N9 microglia were also treated with an Arg1 inhibitor (NOHA) to determine whether pharmacological inhibition inhibited activity or also reduced Arg1 protein expression. Concentrations up to $100 \mu \mathrm{M}$ inhibitor failed to alter protein expression (Fig. 1C,D). Next, we treated N9 cells with IL-4 for 4 h, washed out the IL-4, and then placed the N9 cells in the upper chamber of a coculture dish above human neuroblastoma Be(2)M17 cells for $24 \mathrm{~h}$ with and without the Arg1 inhibitor NOHA (Fig. 1E,F). Tau levels were assessed in the $\mathrm{Be}(2) \mathrm{M} 17$ cells. We found that prior IL-4 
A

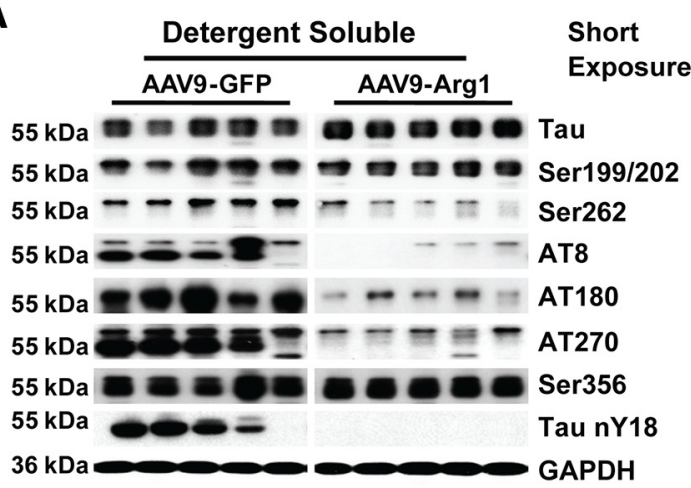

C

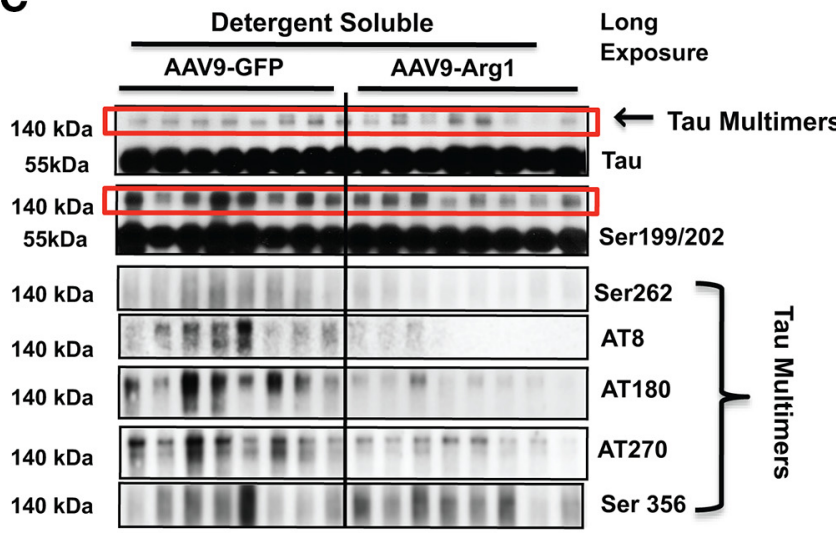

$\mathbf{E}$

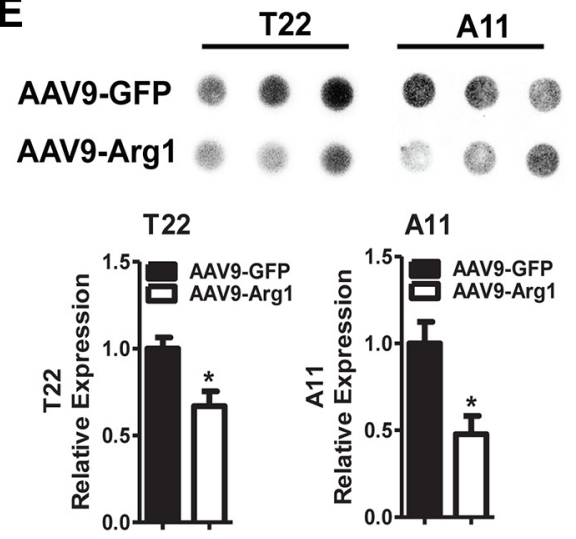

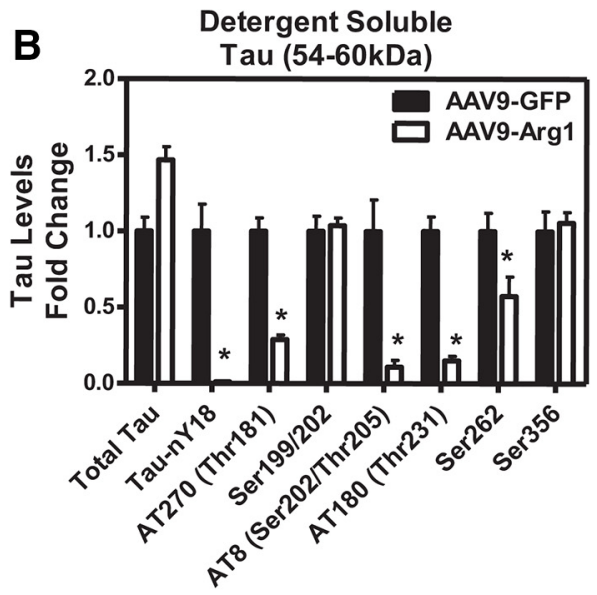

Phospho Tau Epitope

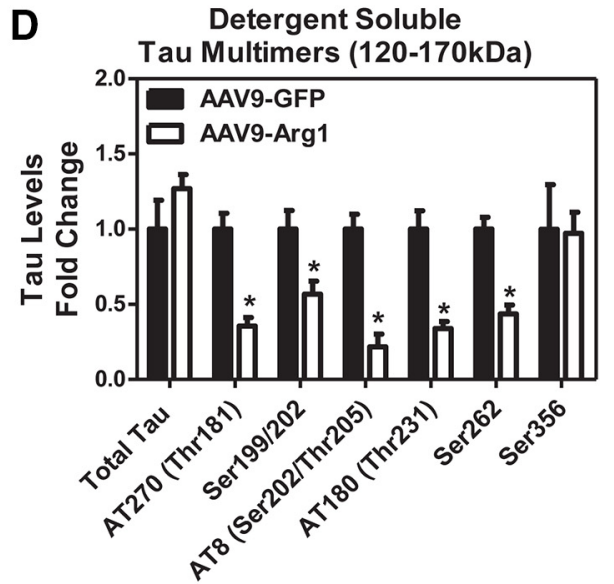

Phospho Tau Epitope

Figure 6. rAAV-mediated Arg1 overexpression lowers several detergent-soluble phospho-tau species. rAAV-Arg1 or rAAV-GFP was injected into the HPC of rTg4510 mice. Protein was extracted using RIPA buffer and Western blot analyses were performed for tau (H150), Ser199/202, Ser262, AT8, AT180, AT270, Ser356, and nitrated tau (nY18) (A). Tau monomers ranging between 50 and $64 \mathrm{kDa}(\boldsymbol{A}, \boldsymbol{B})$, in addition to high-molecular-weight tau multimers $120-170 \mathrm{kDa}(\boldsymbol{C}, \boldsymbol{D})$, were measured and normalized to GAPDH. Fold change in tau and phospho-tau levels were quantified for both the monomer $(\boldsymbol{B})$ and the multimer species (D). Dot blot analysis revealed that Arg1 treatment reduced reactivity to the anti-tau oligomer antibody (T22) and the oligomer-specific A11 antibody compared with GFP controls in rTg4510 mice (E). Group differences were determined using Student test, ${ }^{*} p<0.05 ; n=8 ; 5$ random or 8 samples are displayed in the figure.

treatment of N9 microglia reduced tau levels in Be(2)M17 cells and this reduction was blocked after inhibition of Arg1 at the higher concentration of NOHA (Fig. $1 E, F$ ). This suggests that activation of N9 microglia by IL-4 induced Arg1 expression, which in turn decreased tau levels in cocultured $\mathrm{Be}(2) \mathrm{M} 17$. Furthermore, pharmacological inhibition of Arg1 prevented these tau reductions.

To determine how L-arginine metabolism affected tau biology, we treated C3-HeLa cells with various concentrations of L-arginine (Fig. 2). These cells overexpress human 4R tau due to stable transfection. We found that increasing concentrations of L-arginine promoted total tau levels in addition to increasing phospho-tau Ser396 and phospho-tau Ser199/202 (Fig. 2). Furthermore, $\mathrm{L}$-arginine increased expression of $\mathrm{mTOR}$, a negative regulator of autophagy (Fig. $2 A, B$ ). This suggests that L-arginine metabolism may influence tau levels through modulation of autophagy or decreased degradation.

Because the addition of L-arginine increased levels of tau, we next sought to deplete endogenous levels of L-arginine by overexpressing Arg 1 and determining the impact on tau levels. Therefore, we cloned Arg1 and evaluated the relative enzyme activity 
A

Formic Acid Fraction
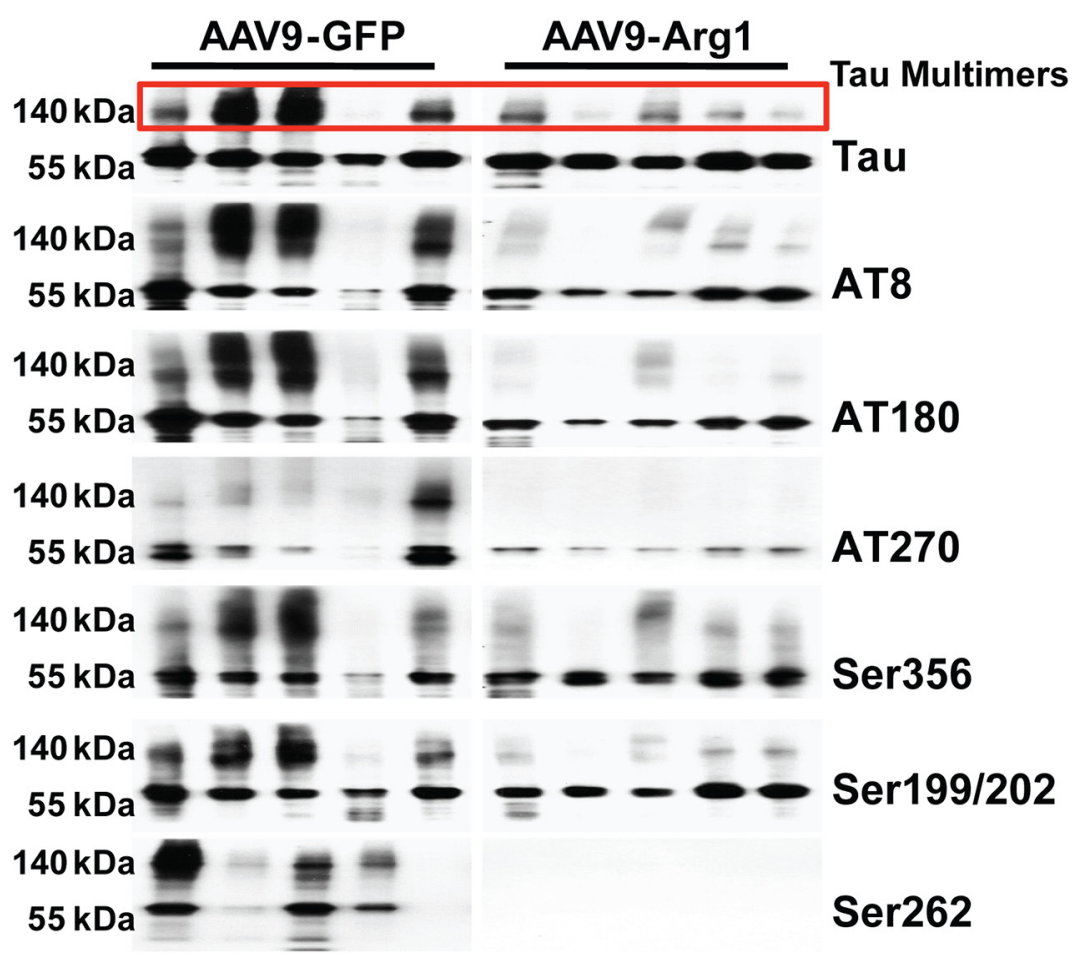

B

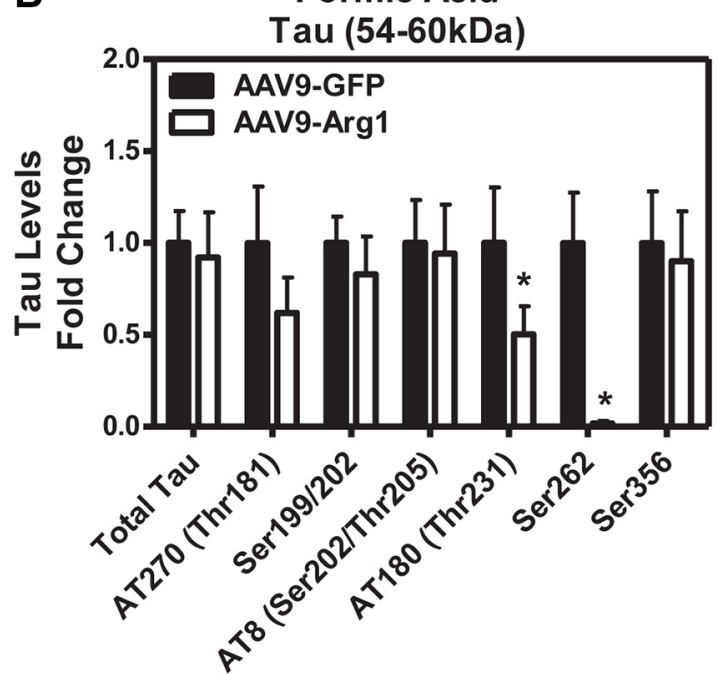

Phospho Tau Epitope
C Formic Acid

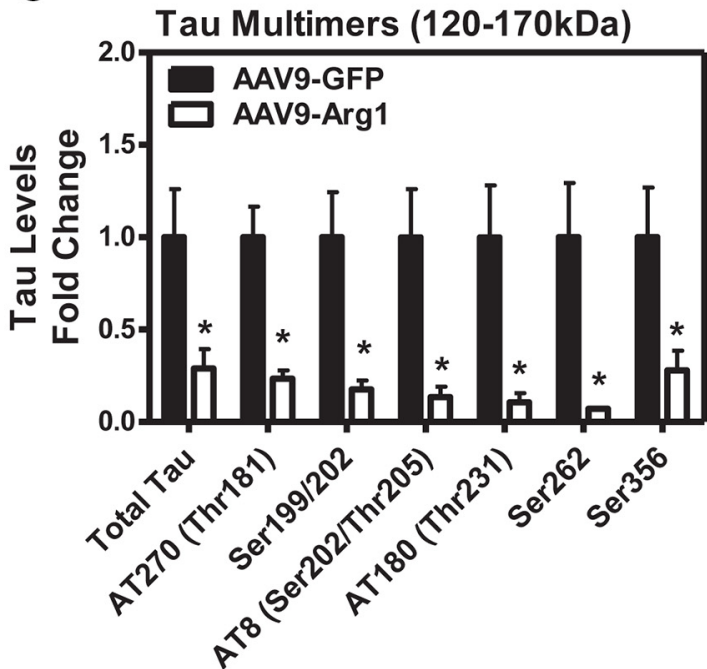

Phospho Tau Epitope

Figure 7. rAAV-mediated Arg1 lowers high-molecular-weight, formic-acid-soluble tau multimers. Detergent-insoluble pellets were extracted using formic acid and Western blot analyses were performed for tau (H150), AT8, AT180, AT270, Ser356, Ser199/202, and Ser262 (A). Taus ranging between 50 and 64 kDa and high-molecular-weight tau ranging between 120 and $170 \mathrm{kDa}$ were analyzed separately and normalized to GAPDH. The fold change in tau and phospho-tau levels were quantitated for both the monomer $(\boldsymbol{B})$ and the multimer $(\boldsymbol{C})$ species. Group differences were determined using Student's $t$ test, ${ }^{*} p<0.05 ; n=8 ; 5$ random samples are displayed in the figure.

after transient transfection in cells. Figure $3 A$ confirms successful transfection and expression of the HA tag. Two micrograms of plasmid DNA increased Arg1 activity in amounts that yielded $\sim 2$ nmoles of urea/min, an enzyme activity similar to that obtained using $0.1 \mu \mathrm{g}$ of purified enzyme (Fig. 3B). Arg1 overexpression was detected by Western blot as well (Fig. $3 C, D$ ). Many tau species were reduced in $\mathrm{C} 3 \mathrm{HeLa}$ cells transfected with the Arg1 plasmid, including total tau (Fig. 3C,E), phospho-tau Ser199/202 (Fig. 3C,F), Ser356 (Fig. 3C, G), and Ser396 (Fig. 3C,H). In addition, mTOR levels were significantly reduced (Fig. 3C,I), suggest- ing the possible involvement of autophagy. Together, these data suggest that L-arginine accumulation increases tau levels, possibly through mTOR signaling, and that arginase overexpression reduces tau species in vitro.

AAV9 delivery of Arg1 and GFP in the mouse hippocampus We next sought to overexpress Arg1 or a control protein (GFP) using rAAV9 delivery to the hippocampus of rTg4510 tau transgenic mice. The rAAV9 constructs use the CBA promoter (a hybrid CMV and chicken $\beta$-actin promoter), which primarily 

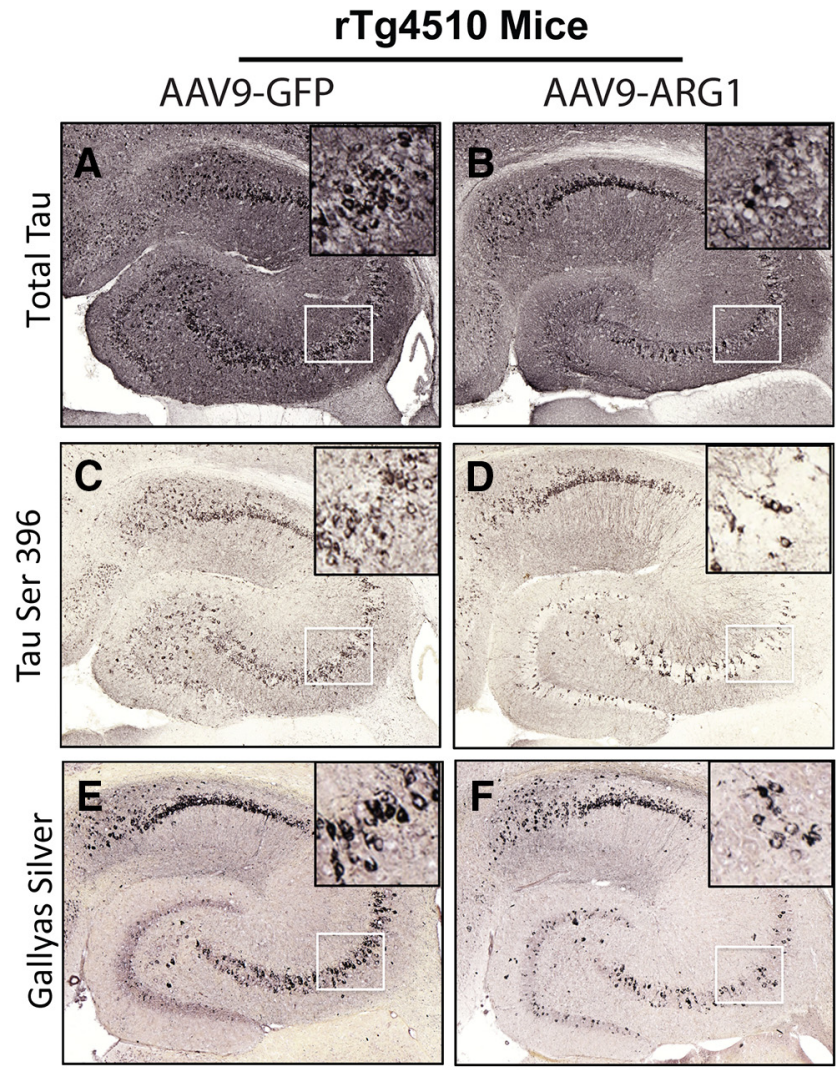

G

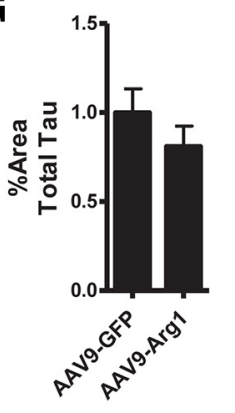

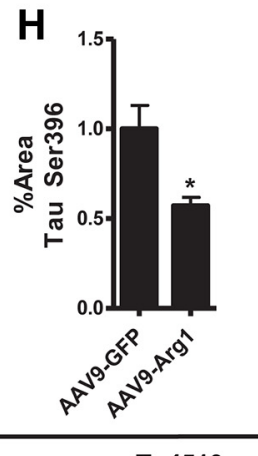

I

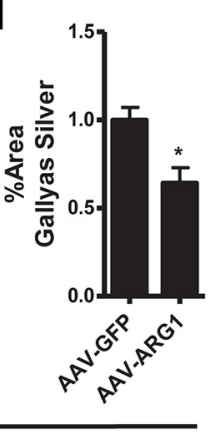

rTg4510

Figure 8. $\quad$ rAAV-Arg1 reduced histopathological tau tangles. Immunohistochemical staining for total tau (H150) after GFP- $(\boldsymbol{A})$ or Arg1 (B)-expressing viruses did not show any significant differences in the percentage area of positive staining $\boldsymbol{G}$. Immunohistochemical staining for phospho-tau Ser396 after GFP- ( $)$ or Arg1 (D)- expressing viruses showed significant reduction in the percentage area of positive staining after $\operatorname{Arg} 1$ expression $(\boldsymbol{H})$. Gallyas silver-positive staining after GFP- $(\boldsymbol{E})$ or $\operatorname{Arg} 1(\boldsymbol{F})$-expressing viruses showed significant reduction in the percentage area of positive staining after Arg1 expression (I). The area in the CA3 region of the hippocampus depicted in the white boxes is magnified in the insets. Graphs display image analyses for immunohistochemical/Gallyas silver positive stain. Statistical analyses were performed with the Student test, ${ }^{*} p<0.05 ; n=8$.

expresses in neurons but may also express in astrocytes. rTg4510 tau mice express the human MAPT P301L tau mutation under control of a tetracycline response element crossed with mice that express the tetracycline activator protein driven by Camk2a promoter (Santacruz et al., 2005). Bigenic mice develop inflammation, phospho tau species, pretangles, and tangle pathology. In addition, mice develop severe neuronal loss and atrophy after 5 months of age (Santacruz et al., 2005; Dickey et al., 2009). Fourmonth-old rTg4510 mice were stereotaxically injected in the hippocampus with an rAAV9-Arg1 or rAAV9-GFP construct and tissue was collected 4 months later (Fig. 4). Mice that received rAAV constructs for Arg1 showed high expression levels and distribution of Arg1 throughout the hippocampus (Fig. $4 C, G$ ) compared with rAAV-GFP mice (Fig. $4 B, G$ ) and nontransgenic littermates (Fig. $4 A, G$ ). In addition, the rAAVGFP construct showed significant GFP expression throughout the hippocampus of rTg4510 mice (Fig. $4 E, H$ ) compared with nontransgenic mice (Fig. $4 D, H$ ) and rAAV-Arg1-treated mice (Fig. $4 F, H)$.

To determine the amount of Arg1 activity in the hippocampus of $\mathrm{rTg} 4510$ mice, we measured the relative Arg1 enzyme activity in nontransgenic littermates and mice that received both rAAVGFP and rAAV-Arg1 (Fig. 5A). We found an $~ 30$-fold increase ( $0.34 \mathrm{nmoles}$ urea $/ \mathrm{min} / \mu \mathrm{g}$ protein) in the Arg1 activity in the rAAV-Arg1-treated group compared with nontransgenic $(0.011$ nmoles urea $/ \mathrm{min} / \mu \mathrm{g}$ protein) littermates and mice treated with the $\mathrm{rAAV}-\mathrm{GFP}$ construct $(0.016 \mathrm{nmoles} \mathrm{urea} / \mathrm{min} / \mu \mathrm{g}$ protein $)$, suggesting an increased amount of Arg1 protein and activity in the hippocampus (Fig. 5A). Finally, we determined the relative amount of L-arginine in the hippocampus in nontransgenic littermates and mice that received both rAAV-GFP and rAAVArg1.rTg4510 tau transgenic mice displayed approximately twice the amount of free L-arginine (11.99 $\mu \mathrm{g} / \mathrm{mg}$ soluble protein) compared with nontransgenic littermates $(5.95 \mu \mathrm{g} / \mathrm{mg}$ soluble protein) (Fig. 5B). Conversely, mice treated with rAAV-Arg1 had significantly reduced amounts of free L-arginine $(6.55 \mu \mathrm{g} / \mathrm{mg}$ soluble protein) compared with $\mathrm{rTg} 4510$ tau transgenic mice treated with the rAAV-GFP construct (Fig. 5B). This suggests that rTg4510 mice show increased levels L-arginine and that the rAAV-Arg1 construct normalizes L-arginine to that of control levels.

rAAV9-mediated Arg1 overexpression reduced multiple phospho tau species, tangle pathology, and kinase levels To determine levels of phospho tau epitopes after Arg1 overexpression in the CNS of rTg4510 tau transgenic mice, we extracted tau from a detergent-soluble fraction (S1) and a formic-acidsoluble fraction (solubilized P1). We identified a significant reduction in the detergent soluble fraction of many, but not all, phospho tau species, including Ser262, AT8, AT180, AT270, and nitrated tau Tyr 18 . However total tau levels remained unchanged compared with GFP controls (Fig. 6A,B). Furthermore, highmolecular-weight tau bands (tau multimers of 120-170 kDa, also described and characterized in rTg4510 mice) were measured after longer exposures of the blots (Fig. 6C,D). Arg1 reduced tau multimer levels, as visualized after staining for epitopes Ser199/ 202, Ser262, AT8, AT180, and AT270 (Fig. 6C,D). In addition, dot blot analysis revealed that Arg1 treatment reduced reactivity to the anti-tau oligomer antibody (T22) and the oligomerspecific A11 antibody compared with GFP controls in rTg4510 mice (Fig. 6E). This suggests that sustained Arg1 reduced several phosphor-epitopes of tau as monomer, oligomer, and highmolecular-weight species.

For the detergent-insoluble tau (formic acid fraction), we observed reductions in several tau species between 54 and 64 $\mathrm{kDa}$ and lower levels of tau for AT270 and AT180 (Fig. 7 A, B) after formic acid extraction. In addition, we noted more global reductions in high-molecular-weight tau multimers (120-170 $\mathrm{kDa}$, which did not require overexposure in this fraction) for Ser199/202, Ser356, Ser262, AT8, AT270, AT180, and total tau after Arg1 overexpression compared with GFP controls (Fig. $7 A, C)$. This suggests that rAAV-mediated Arg1 overexpression reduces tau phosphorylation in multiple intracellular pools. 
rTg4510 Mice
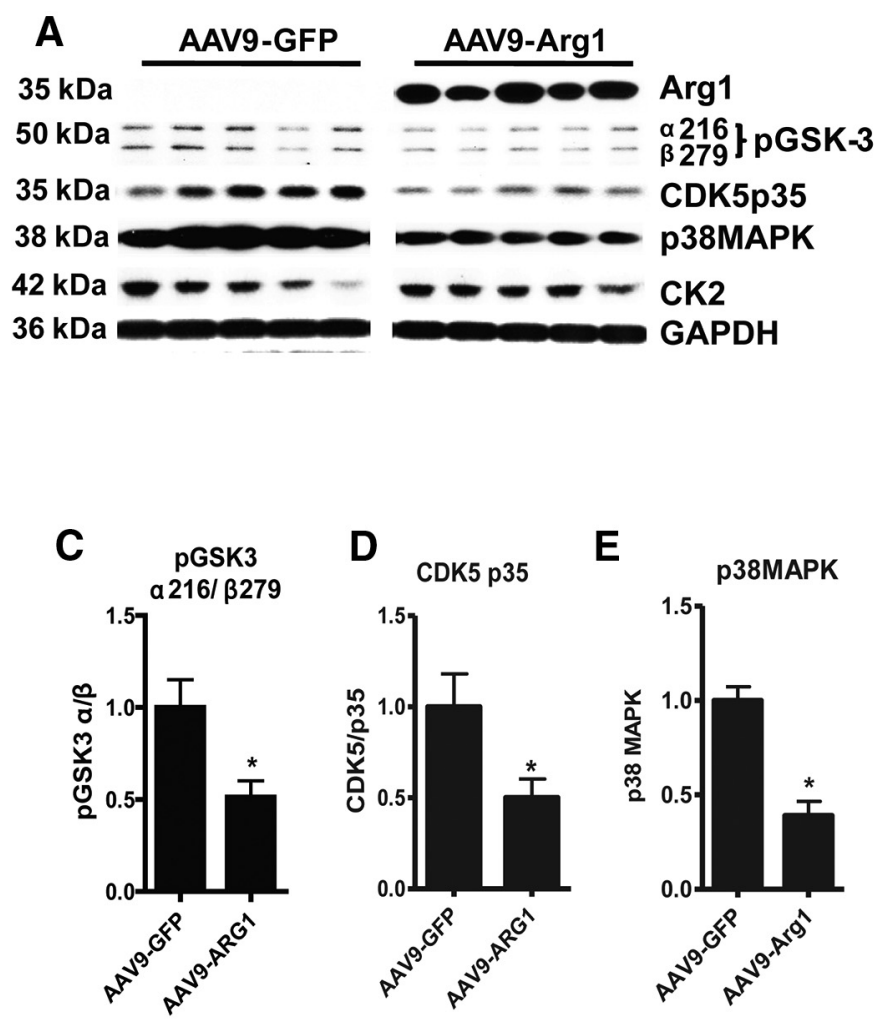

D

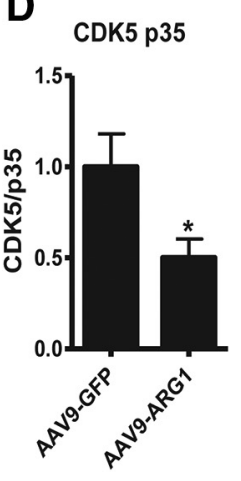

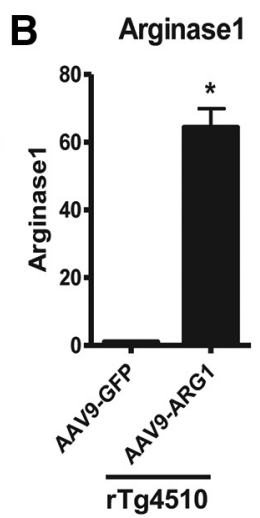

E

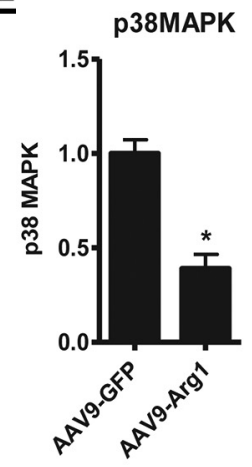

rTg4510

Figure 9. $\quad$ rAAV-mediated Arg1 overexpression reduced tau kinases. Western blot analyses were performed on several kinases associated with tau phosphorylation after stereotaxic injections of rAAV-Arg1 or rAAV-GFP into the hippocampus of rTg4510 mice (A). Western blots for Arg1 (B), phospho GSK3 $\alpha 279$ /beta216 (C), CDK5/p35 (D), p38MAPK (E), and casein kinase 2 (CK2; $\boldsymbol{F})$ were analyzed and normalized to GAPDH. rAAV-mediated Arg1 overexpression reduced phospho GSK3 $\alpha 279 /$ beta216, CDK5/p35, p38MAPK, but failed to reduce CK2. Student's $t$ test, ${ }^{*} p<0.05 ; n=8$.

To qualitatively detect reductions in phospho tau and to identify neurofibrillary tangles after rAAV9-Arg1 overexpression, we performed immunohistochemical analysis for tau Ser 396 and total tau and histopathology using Gallyas silver stain. Although total tau levels (Fig. 8A,B,G) did not significantly change, tau Ser396 (Fig. $8 C, D, H)$ was significantly reduced in the hippocampus compared with rAAV9-GFP controls. In addition, AAV9-Arg1 also reduced tangle pathology measured by Gallyas silver stain compared with rAAV9-GFP controls (Fig. 8E,F,I) in the hippocampus. These data demonstrate that rAAV9-Arg1 overexpression reduces several phospho tau epitopes, including high- molecular-weight multimers, measured both neurochemically and histologically.

As expected, Arg1 significantly increased in the dissected region of the hippocampus as measured by Western blot (Fig. 9A,B). We found that rAAV9-mediated Arg1 overexpression (Fig. 9A) significantly reduced glycogen synthase kinase-3 (pGSK-3 $\alpha 216 / \beta 279$ ) (Fig. $9 A, C$ ), a phospho-epitope that confers increased activity, CDK5p35 (Fig. 9A,D), and p38MAPK expression (Fig. 9A, E) compared with rAAV9-GFP controls. However, casein kinase II expression remained unaltered (Fig. 9A,F) suggesting that Arg1 overexpression does not exert a global effect on kinases, but has some selectivity in reducing tau-associated kinases.

rAAV9-mediated Arg1 overexpression activates autophagy As another possible explanation for clearance of tau after Argl overexpression, we measured autophagy-related proteins. rTg4510 mice

$\mathbf{F}$

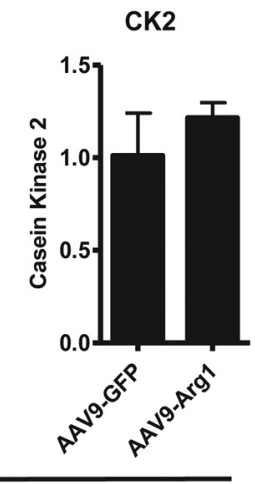

accumulate significant amounts of tau and exhibit impaired autophagy. When the rate of autophagy is reduced, sequestosome-1 (p62) levels accumulate; this increase has served as an index of autophagy or general protein accumulation by others (Kuusisto et al., 2003; Sacino et al., 2014). We observed global accumulation of p62 throughout the cortex (Fig. 10A-D), hippocampus (Fig. $10 E, F)$, and other regions of rTg4510 tau mice compared with nontransgenic mice (Fig. 10A,B). Therefore, we sought to determine whether rAAV9-Arg1 overexpression increased autophagy in rTg4510 tau mice compared with rAAV9-GFP controls. Similar to cell culture data (Fig. 3), rAAV9-Arg1 overexpression significantly decreased mTOR (Fig. 10H) and components of the mTOR complex 1 (mTORC1) including, phospho mTOR Ser2481 (Fig. 10I), g $\beta \mathrm{L}$ (Fig. 10K), raptor (Fig. 10M), and p62 (Fig. $10 L$ ), compared with rAAV9-GFP controls. In contrast, putative components of the mTORC2 complex were not reduced, including phospho mTOR Ser2448 (Fig. 10J) and rictor (Fig. 10N), This suggests that rAAV9-Arg1 overexpression stimulates autophagy in rTg4510 tau mice by negatively regulating $\mathrm{mTOR}$ signaling.

\section{Arg1 overexpression decreases inflammation in $\mathrm{rTg} 4510$ mice}

Arg1 and polyamines have been shown to modify inflammation in various models (Paul and Kang, 2013; França-Costa et al., 2015; Weisser et al., 2014; Kan et al., 2015); therefore, we measured activation of myeloid cells and several proinflammatory cytokines after rAAV9-Arg1 overexpression. Using image analyses, we measured activation of myeloid cells in the hippocampus by immunohistochemistry using IBA-1, CD68, and CD45 in rTg4510 mice that received either rAAV9-GFP or rAAV9-Arg1 (Fig. 11). Overall, activation of myeloid cells was significantly increased in rTg4510 mice compared with nontransgenic littermates (Figs. 11, 12). Arg1 overexpression significantly reduced IBA-1 (Fig. 11A-C,I) and CD45 (Fig. 11G, H, K) expression compared with GFP control mice in rTg4510 tau mice (Fig. 11), whereas CD68 showed comparable expression between both the rAAV9-Arg1-treated and rAAV9-GFP-treated groups in rTg4510 mice (Fig. 11D-F,J).

We used a cytokine array to determine relative protein levels of specific cytokines. Several cytokines were significantly elevated in rTg4510 tau mice, including IL-1 $\beta$, IL-12, KC/Gro, IL-10, and IFN- $\gamma$, compared with nontransgenic littermates (Fig. 12); others that were measured but did not change included IL-2, IL-4, and IL-5 (data not shown). rAAV9-Arg1 overexpression significantly reduced all of the aforementioned cytokines and inflammatory markers compared with rAAV9-GFP control animals (Fig. 12A$E$ ). In addition, IL- $1 \beta$ (data not shown) and TNF- $\alpha$ levels (Fig. $12 F$ ) were measured by ELISA. Both cytokines were elevated in rAAV9-GFP-treated mice compared with nontransgenic mice. Similarly, rAAV9-Arg 1 significantly reduced IL-1 $\beta$ and TNF- $\alpha$ in rTg4510 mice via ELISA compared with GFP control mice (Fig. $12 F)$. These data suggest that inflammation is increased in 


\section{rTg4510 Mice}

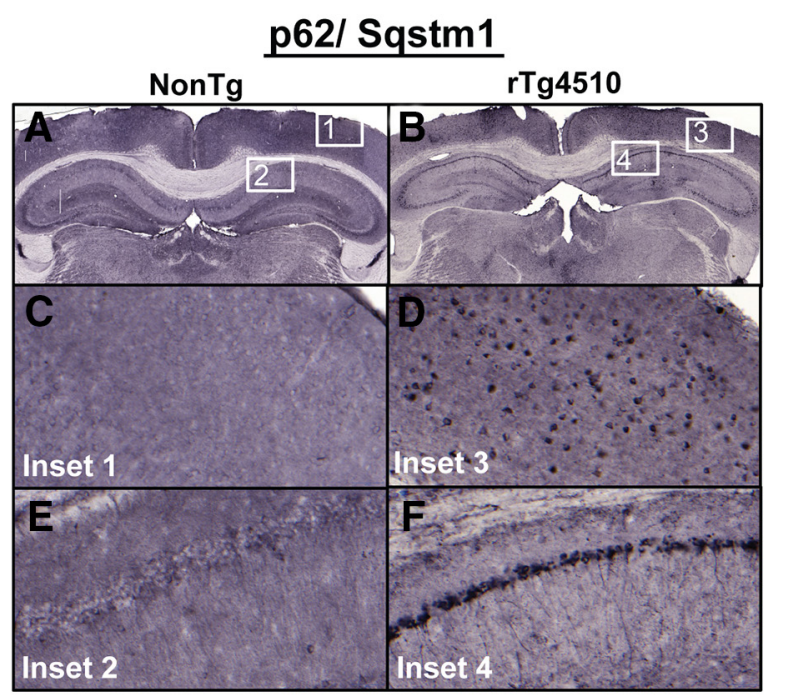

rTg4510 Mice

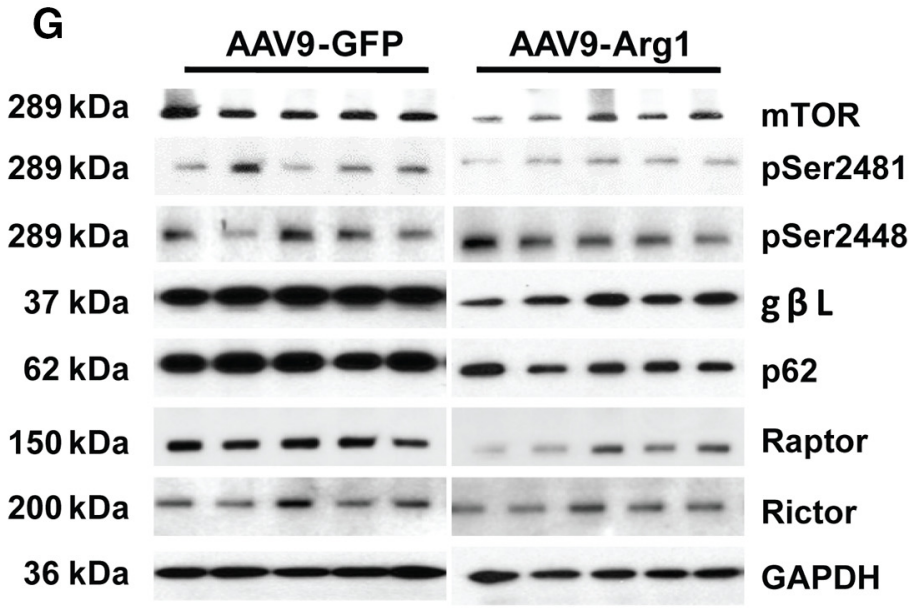

H

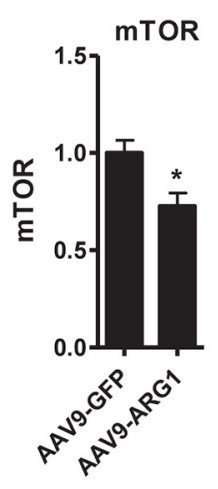

I

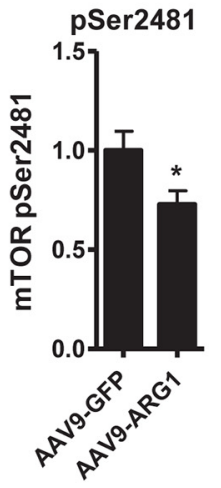

J

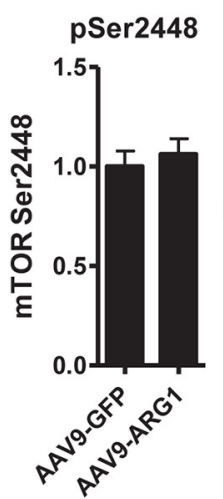

K

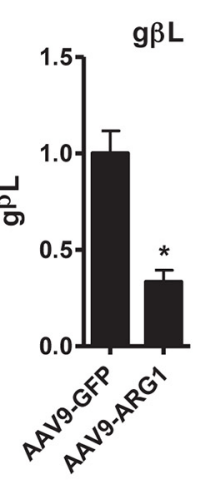

L

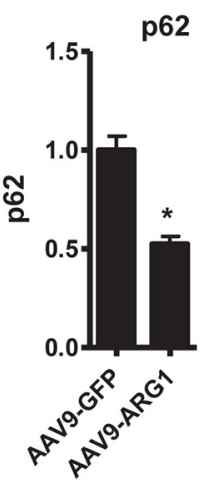

M

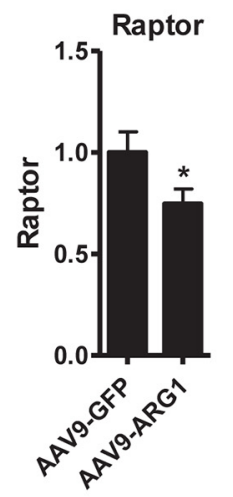

N

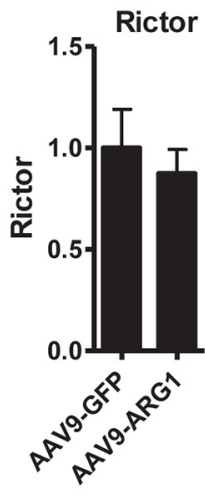

rTg4510

Figure 10. rAAV-Arg1 induced changes in autophagy-related proteins. Compared with nontransgenic littermates $(\boldsymbol{A}, \boldsymbol{C}, \boldsymbol{E})$, rTg5410 mice $(\boldsymbol{B}, \boldsymbol{D}, \boldsymbol{F})$ show global accumulation of p62/sqstm1 staining in the cortex and hippocampus. The boxed areas are shown at higher magnification in $\boldsymbol{C}-\boldsymbol{F}$. $\boldsymbol{C}$ and $\boldsymbol{D}$ depict cerebral cortex and $\boldsymbol{E}$ and $\boldsymbol{F}$ depict the $\mathbf{C A} 1$ region of the hippocampus. In rAAV-Arg1- and rAAV-GFP-injected rTg4510 mice, autophagy-related proteins were measured by Western blot analyses (G). Quantitation of mTOR $(\boldsymbol{H})$, pmTOR 2481 (I), pmTOR $2448(\boldsymbol{J}), \mathrm{g} \beta \mathrm{L}(\boldsymbol{K})$, p62 $(\boldsymbol{L})$, raptor $(\boldsymbol{M})$, and rictor $(\boldsymbol{N})$ normalized to GAPDH are shown. Arg1 overexpression significantly reduced several autophagy-related proteins. Student's $t$ test, ${ }^{*} p<0.05 ; n=8$.

rTg4510 tau transgenic mice and that rAAV9-Arg1 overexpression significantly mitigates microglial activation and reduces cytokine activation in rTg4510 tau transgenic mice.

rTg4510 tau mice develop significant neuronal loss, as well as cortical and hippocampal atrophy. As expected, rTg4510 tau mice that received rAAV9-GFP showed significant neuronal loss and hippocampal atrophy compared with nontransgenic littermates. rAAV9-Arg1 overexpression failed to prevent neuronal loss by unbiased stereology (Fig. 13A-D), but significantly slowed hippocampal atrophy (Fig. 13A-C,E).

Conditional Arg1 depletion modifies the response to inflammation and affects tau progression

We used Cre Lox Arg1 mice (Arg1 LoxP/LoxP $)$ crossed with the Cre deleter strain (LysMcre ${ }^{+/-}$), which has been shown to target cells of myeloid lineage, primarily macrophages and a certain percentage of microglia (Ros-Bernal et al., 2011; Cho et al., 2015). We generated bigenic conditional floxed Arg1 mice referred to herein as $\operatorname{Arg} 1^{\mathrm{fl} / \mathrm{fl}} /$ LysMcre mice (unless otherwise genotypically speci- fied). We determined the effects of Arg1 deletion in myeloid cells on inflammation and pathogenic tau. The LysMcre knock-in allele contains a nuclear-localized Cre recombinase inserted into the first coding ATG of the lysozyme 2 gene ( Lyz2). Homozygous mice for LysMcre produce a knock-out of the Lyz2 gene.

To determine the role of Arg1 expression in the CNS after inflammation, we injected LPS into the CNS of Arg1-sufficient mice $\left(\mathrm{Argl}^{+1+} / \mathrm{LysMCr}^{-/-}\right)$and conditional Arg1-null $\left(\right.$ Argl ${ }^{\mathrm{fl} / \mathrm{fl}} /$ LysMcre $\left.^{+/-}\right)$mice. Three days after injection, brains were harvested to determine the induction of myeloid cell activation and the level of Arg1 expression in the CNS. A general myeloid marker, CD11b, was used to measure the extent to which activation occurred. Both genotypes showed comparable levels of CD11b activation (Fig. 14A, B,G). However, Arg1 was significantly diminished in conditional Arg1-null mice $\left(\operatorname{Arg} 1^{\mathrm{fl} / \mathrm{fl}} /\right.$ LysMcre ${ }^{+/-}$) compared with Arg1-sufficient mice $\left(\mathrm{Argl}^{+1+} /\right.$ LysMCre $^{-I^{-}}$), suggesting conditional deletion of Argl in brain (Fig. 14C, D, $G$ ). In addition, induction of YM1 was also reduced 


\section{rTg4510 Mice}

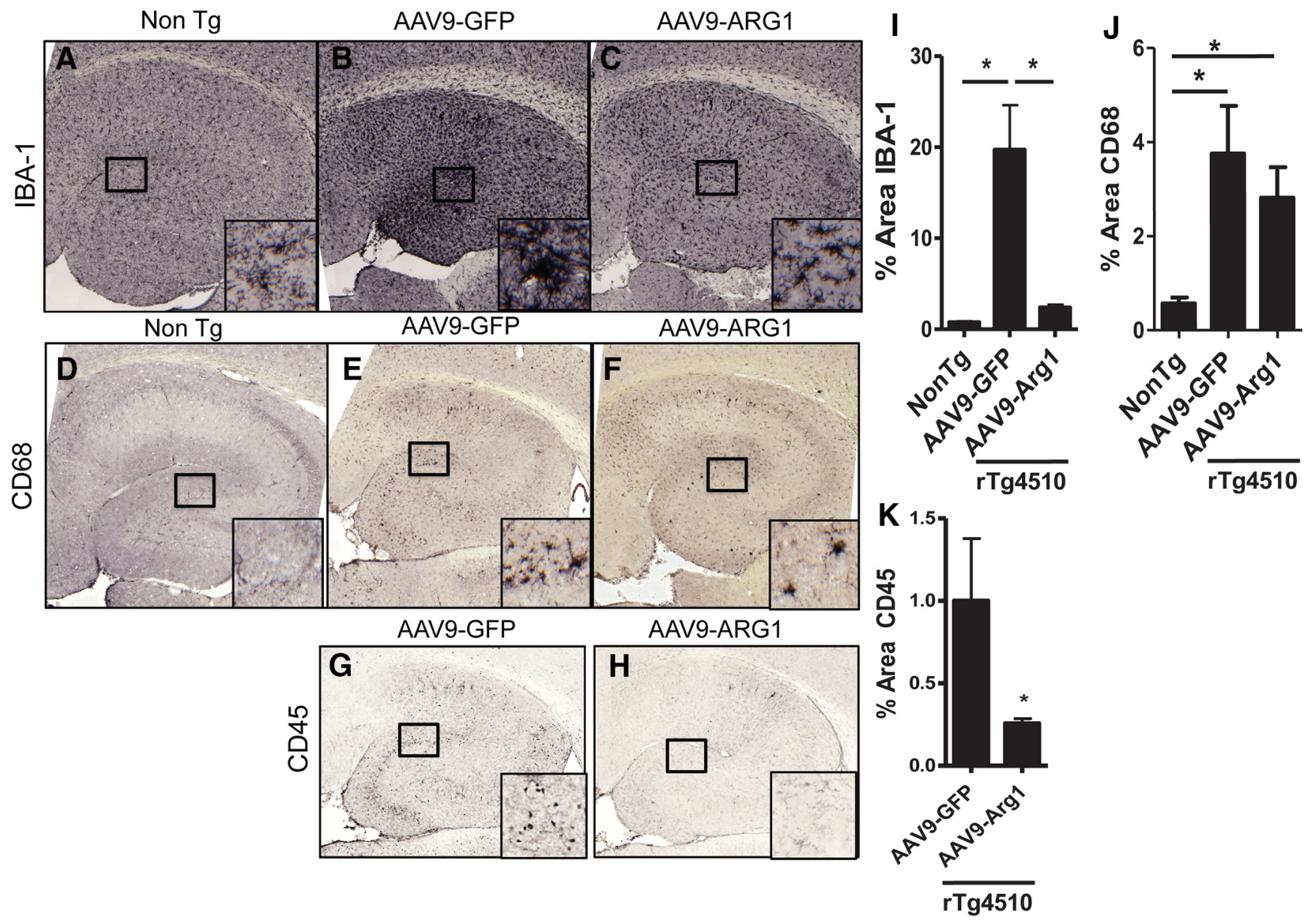

Figure 11. Arg1 overexpression modulates microglia activation. Immunohistochemistry for the microglial markers IBA-1 (A-C), CD68 (D-F), and CD45 (G-H) after rAAV-GFP or rAAV-Arg1 treatment is shown compared with nontransgenic (NonTg) mice. rAAV-Arg1 reduces IBA-1 $(\boldsymbol{I})$ and CD45 $(\boldsymbol{K})$ expression compared with rAAV-GFP treated mice, but CD68 $(\boldsymbol{J})$ was unchanged. Graphs display image analyses for immunohistochemistry of the percentage area staining in the hippocampus for IBA-1, D68, and CD45. Statistical analyses were performed using ANOVA with Fisher's multiple-comparison test or Student's $t$ test, ${ }^{*} p<0.05 ; n=6-8$.

in Arg1-null mice (Fig. 14E-G), signifying that Arg1 may modulate microglial phenotype.

To determine floxing efficiency in the brains of mice, we measured Arg1 and Lyz2 (gene product of LysM promoter) mRNA transcripts from the hippocampus of mice using qRT-PCR. We measured Arg1 (for conditional deletion and floxing efficiency) and Lyz2 (wild-type, hemizygous, and homozygous knock-out alleles) mRNA transcripts from various genotypes and treatments. In addition, we measured whether tau affected the Arg1 and Lyz2 mRNA transcripts. Arg1-sufficient wild-type $\left(\operatorname{Arg} 1^{+1+} /\right.$ LysMCre ${ }^{-1-}$ ) and conditional Arg1 knock-out (Arg1 ${ }^{\mathrm{fl} / \mathrm{fl} /}$ Lys $\mathrm{MCre}^{+/-}$) mice were injected with an rAAV consisting of a pathological neoepitope and caspase cleavage form of human C-terminal truncated tau (D421) (Fig. 15A). Caspase cleaved tau (1-421 [D421]) is secreted more readily than wild-type tau (Plouffe et al., 2012), can nucleate and recruit additional tau molecules to form pathological conformations (de Calignon et al., 2010), and remains an early event of tangle pathology (Rissman et al., 2004). Furthermore, caspase cleaved tau (D421) is preferentially cleared through the autophagy pathway (Dolan and Johnson, 2010).

Wild-type Arg1 $\left(\mathrm{Arg}^{+/+} / \mathrm{LysMcre}^{-/-}\right)$mice were used as a baseline control for Arg1 mRNA transcript levels in the hip- pocampus (Fig. 15A). Treatment with rAAV-tau CT (D421) significantly reduced the Arg1 mRNA transcript by $>50 \%$ after 4 months in Arg-sufficient mice, but by $80 \%$ in floxed Arg1 mice $\left(\mathrm{Arg}^{\mathrm{fl} / \mathrm{ll} /} / \mathrm{Lys} \mathrm{Mcre}^{+/-}\right)$(Fig. 15A). These data suggest that pathological tau reduces Arg1 mRNA transcripts and that the LysMcre promoter can significantly lower mRNA transcripts for Arg1 in the brains of $\left(\operatorname{Arg}^{\mathrm{f} / \mathrm{fl}} / \mathrm{LysMcre}{ }^{+/-}\right)$mice (Fig. 15A). Further, we measured the levels of the Lyz2 mRNA transcript in the hippocampus; however, mice homozygous for $\mathrm{LysMcre}^{+/+}$and deemed a Lyz2 knock-out exhibited reduced amounts $(>100$ fold decreased) of the Lyz2 mRNA transcript compared with wild-type mice $\left(\mathrm{LysMcre}^{-1-}\right)$ mice verifying a biallele cre knockin/Lyz2 knock-out genotype (Fig. 15B). We also measured the Lyz2 mRNA transcript in the hippocampus after the rAAVtau-CT (D421). We found that the rAAV-tau-CT (D421) construct significantly increased the Lyz2 mRNA transcript (8-fold) in wild-type mice $\left(\mathrm{Lys} \mathrm{Mcre}^{-1-}\right)$ compared with wild-type mice that did not receive the tau construct. However, LysMcre ${ }^{+/-}$ treated with rAAV-tau-CT (D421) only showed a twofold increase in the Lyz2 mRNA transcript compared with wild-type mice $\left(\right.$ Lys Mcre ${ }^{-1-}$ ) with no treatment and a 75\% decrease in Lyz2 mRNA transcript compared with wild-type mice 
(LysMcre ${ }^{-1-}$ ) mice treated with rAAVtau-CT (D421) (Fig. 15B). These data suggest that pathological tau (rAAV-tau-CT, D421) induces the Lyz2 mRNA transcript, which would be presumed to facilitate floxing efficiency of the LysMcre promoter. Further, it suggests that the Lyz2 mRNA transcript is present in the brain in amounts that are readily detectable and can be enhanced with pathological tau. Together, this decreases the mRNA transcript for Arg1. It should be noted that the increased levels of Lyz2 mRNA transcript could arise from peripheral myeloid cells entering the brain, especially after tau deposition.

Finally, we sought to determine how Arg1 deletion in myeloid cells affects pathogenic tau. Both $\operatorname{Arg} 1^{+/+} /$LysMcre $^{-/-}$and Arg $^{\mathrm{t} / / \mathrm{ll} /}$ LysMcre ${ }^{+/-}$mice received a single intracranial injection of the rAAV-Tau-CT (D421) construct and were allowed to survive for 4 months. Immunohistochemical analysis showed that the overall mean for total tau levels was comparable between both genotypes (Fig. 16E, F, I, L). However, immunohistochemical staining for tau AT8 (Ser202/Thr205; Fig. 16A, B,G,J) and Ser199/202 (Fig. 16C,D,H,K) were increased in Arg1 knock-out $\left(A r g^{\mathrm{fl} / \mathrm{fl}} /\right.$ LysMcre ${ }^{+/-}$) mice compared with Arg1sufficient mice $\left(\right.$ Arg $1^{+/+} /$LysMcre $\left.^{-/-}\right)$. These data suggest that Arg1 deficiency may also affect tau pathology in a direction opposite that of Arg1 overexpression.

\section{Discussion}

Herein, we overexpressed Arg1 at a time when tau deposits were beginning to develop (Dickey et al., 2009). The potential implications and generality of these findings, namely the reduction in tau deposition after Arg1 overexpression, make these data intriguing. We observed a reduction in several phospho tau epitopes and nitrated tau Tyr18. Tau nitrated at Tyr18 has been linked to increased positive expression in astrocytes (Reyes et al., 2008). It is conceivable that the reduction in tau-nY18 seen in our study (Fig. 6) may result from astrocytic or neuronal expression of rAAV-mediated Arg1 and shunting arginine away from NOS-mediated nitric oxide production. In addition, we observed a decrease in specific kinases associated with phosphorylation of tau epitopes, reduced immune cell activation and cytokine expression, and activation of autophagy through mTOR signaling. The decrease in phospho-epitopes could originate from a concomitant reduction in several tau kinases such as GSK3, p38, CDK5 or others we did not investigate and/or a combination of other factors (i.e., inflammation, autophagy). Tau has the potential to be phosphorylated at $>80$ putative sites; therefore, it is difficult to predict which phospho-epitopes and kinases are true indicators of taumediated pathogenesis in rTg4510 mice and how Arg1 overexpression reduces specific hallmarks. In addition, several formictest, ${ }^{*} p<0.05 ; n=6-8$.

\section{Cytokine Array}

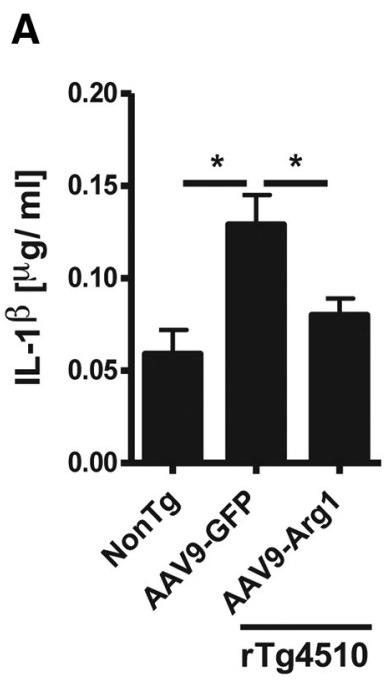

B

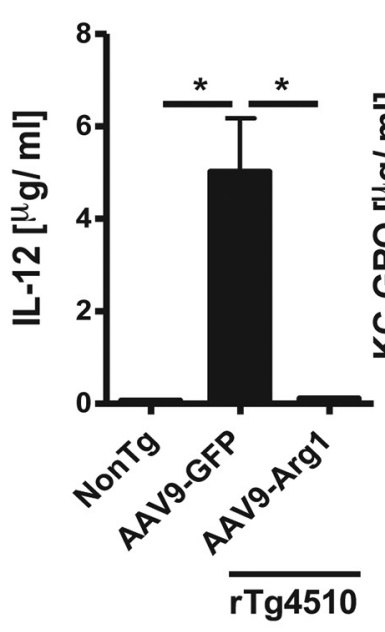

C

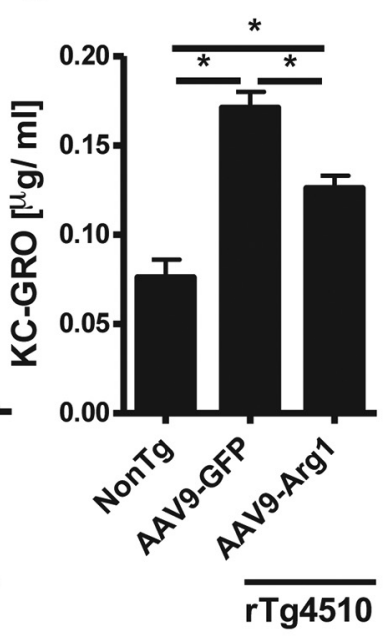

$\mathbf{E}$

$\mathbf{F}$
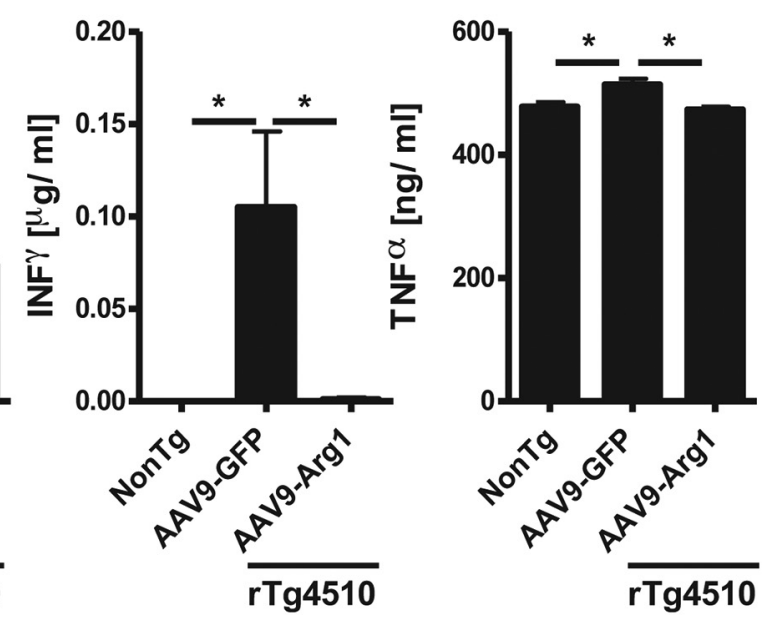

Figure 12. Cytokine array and ELISA for inflammation markers. Cytokine array or ELISA was used to measure inflammation sion reduced inflammation markers IL-1beta $(\boldsymbol{A})$, IL-12 (B), KC-Gro (C), IL-10 (D), IFN-gamma (E), and TNF- $\alpha(\boldsymbol{F})$ compared with AAV-GFP-treated mice. Statistical analyses were performed using ANOVA with Fisher's multiple-comparison test or Student's $t$

acid-soluble tau epitopes and high-molecular-weight species were also reduced with Arg1 treatment. These data suggest that Arg1 may prevent phosphorylation and formation of insoluble high-molecular-weight tau species and subsequent tangle formation as measured by Gallyas silver histopathology (Fig. 8).

As seen in Figure 10, $A-F$, tau mice show accumulation of $\mathrm{p} 62$ in neurons throughout the brain that is consistent with the notion of impaired autophagy or slower protein turnover. Arg1 treatment significantly reduced p62 and signaling components of mTORC1, which also associates with amino acid signaling (Wullschleger et al., 2006; Sancak et al., 2008). This is consistent with the possible explanation that L-arginine depletion by sustained Arg1 overexpression negatively regulates mTOR via L-arginine amino acid sensing negative feedback regulation. Several reports have shown that arginine deprivation by arginine deiminase or Arg1 activates autophagy in cancer cells by decreas- 


\section{rTg4510 Mice}
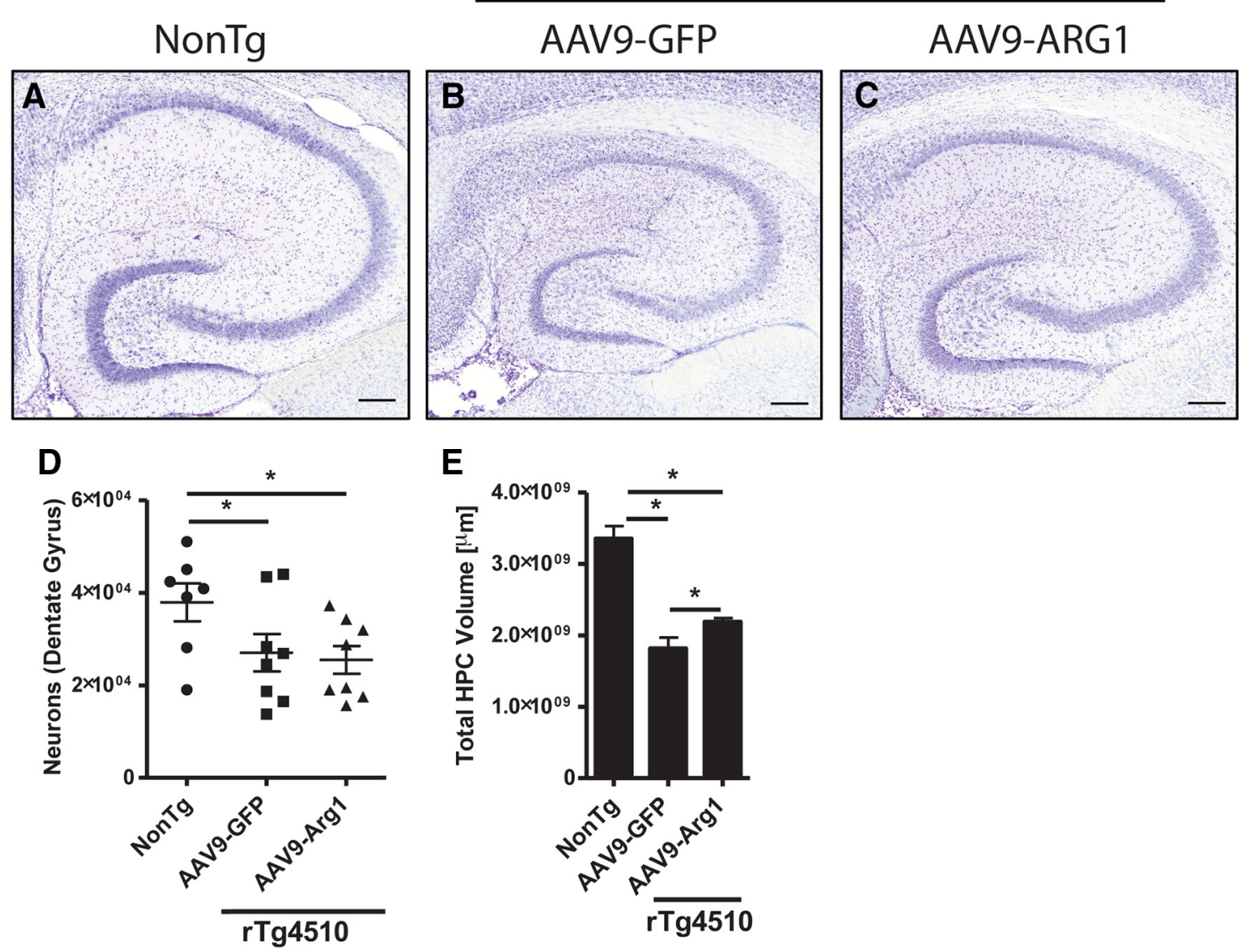

Figure 13. rAAV-Arg1 fails to rescue neuronal loss but mitigates hippocampal atrophy. Nissl staining of the hippocampus of nontransgenic (NonTg) $(\boldsymbol{A})$, rAAV9-GFP-injected rTg4510 (B) and rAAV9-Arg1-injected $\operatorname{rg} 4510(\boldsymbol{C})$ is shown. Neuronal cell counts of the dentate gyrus ( $\boldsymbol{D}$ ) and hippocampal volume (E) were quantified by unbiased stereology. rAAV-Arg1 failed to prevent neuronal loss within the dentate gyrus of the hippocampus $(\boldsymbol{D})$ but reduced hippocampal atrophy $(\boldsymbol{E})$ compared with the rAAV-GFP construct. Statistical analyses were performed using ANOVA with Fisher's multiple-comparison test, ${ }^{*} p<0.05 ; n=6-8$.

ing mTOR signaling (Savaraj et al., 2010; Wu et al., 2011; Hsueh et al., 2012). L-Arginine dietary supplementation increases mTOR-signaling activity (Yao et al., 2008). Some studies indicate that L-arginine activates this signaling cascade in a rapamycinsensitive manner (Ban et al., 2004; Banik et al., 2013), whereas other reports argue that inhibition of autophagy through $\mathrm{L}$-arginine is mTOR independent (Angcajas et al., 2014).

Arg1 is typically used as a marker of inflammation; therefore, we determined the impact of overexpressing Arg1 in the CNS during tau pathology using rAAV. Microglial activation via intracranial LPS or proinflammatory cytokines mitigates amyloid $\beta$ deposition (DiCarlo et al., 2001; Herber et al., 2004; Herber et al., 2007), but can exacerbate tau pathology (D.C. Lee et al., 2010), suggesting that inflammatory by-products govern the pathological outcomes of amyloid versus tau differently. Some reports demonstrate a hybrid activation state (both pro-inflammatory and anti-anti-inflammatory) in the brains of $\mathrm{AD}$ patients and amyloid- $\beta$-depositing mice (Colton et al., 2006), whereas others report shifting from an alternative activation state to a classical activation state later in disease during amyloid deposition (Jimenez et al., 2008). It is likely that a continuum of activation profiles exist during low-grade chronic pathology. Our data suggest that the overexpression of Arg1 may also reduce inflammatory profiles during tau deposition, signifying the complexity of individual by-products of inflammation.
Although immune cells exhibit robust expression of Arg1 through the canonical IL-4/IL-13 JAK/STAT pathway (Welch et al., 2002; Mantovani et al., 2004; Nolan et al., 2005; Martinez et al., 2009; Varin and Gordon, 2009), neurons also express low levels of Arg1 and 2 (Yu et al., 2001, 2002, 2003; Peters et al., 2013; Quirié et al., 2013) and may counter neuronal NOS activity via substrate competition. Recent studies demonstrate transient expression of iNOS in neurons and increased expression in microglia after inflammation (Béchade et al., 2014). In addition, expression of iNOS has also been demonstrated in astrocytes (Jimenez et al., 2008).

Generation of free nitric oxide can perpetuate posttranslational modifications of aggregation-prone proteins such as tau (Reynolds et al., 2006; Reyes et al., 2008; Reyes et al., 2011; Reyes et al., 2012), amyloid $\beta$ (Kummer et al., 2011), and $\alpha$-synuclein (Kotzbauer et al., 2004; Yu et al., 2010; Liu et al., 2011).

As this manuscript was being completed, Kan et al. (2015) published data showing that arginine deprivation leads to immune suppression and changes in amyloid deposition and that inhibition of arginase and ornithine decarboxylase using the drug difluormethylornithine dramatically reduced amyloid deposition in an unusual mouse model of amyloid deposition (NOS2-null background). This led to diminished changes in microglial expression and improved memory performance. Although these data would contradict the use of agents increasing arginase activity in $\mathrm{AD}$, several examples dem- 
onstrate that some manipulations have the opposite effects upon amyloid versus tau deposition in mouse models. Our own work with LPS finds that acute intracranial injections reduce amyloid pathology but enhance tau pathology (Herber et al., 2004; Herber et al., 2007; D.C. Lee et al., 2010) and that both acute (Lee et al., 2013a) proinflammatory and anti-inflammatory cytokines treatments reduce amyloid burden. Bruce Lamb's group reported that CX3CR1 deletion reduced amyloid deposition, but exacerbated tau deposition (Bhaskar et al., 2010; S. Lee et al., 2010). Kerry O'Banion's group found that IL-1 overexpression lowered amyloid and increased tau pathology in different models (Shaftel et al., 2007; Ghosh et al., 2013). It is difficult to equate the role of arginine metabolism during inflammation in different mouse models (amyloid versus tauopathies). However, our data (Fig. 2) show that increasing levels of L-arginine promote tau accumulation at the cellular level in parallel with mTOR accumulation, consistent with the possibility that L-arginine levels modulate autophagy, conceivably through amino acid sensing. In addition, tau transgenic mice showed significant accumulation of L-arginine (Fig. $5 B)$ in the hippocampus compared with nontransgenic littermates and overexpression of Arg1 ( 30-fold) reduced L-arginine levels to that of nontransgenic littermates. Modulation of arginine may explain in part some of these affects on the tau phenotype. Clearly, however, our study and that of Kan et al. (2015) indicate that modulation of arginine metabolism can have a profound impact upon pathologies associated with the development of $\mathrm{AD}$. A recent report indicated significant changes in arginine and polyamine metabolism between control patients, mild cognitive impairment, and $\mathrm{AD}$ converters from plasma using metabolomics profiling (Kyrkanides et al., 2007).

These data signify the impact of L-arginine turnover and the possible effect on autophagy. Double knock-out mice for Arg1 and Arg2 die within $14 \mathrm{~d}$ and show an $\sim 10$-fold decrease in the polyamine precursor ornithine coupled with a marked 100-fold increase in arginine levels throughout various tissues, including brain, compared with wild-type mice (Deignan et al., 2006). In addition, downstream products of arginase, polyamines, generally decline with age (Scalabrino and Ferioli, 1984), but have been shown to increase autophagy, restore memory, and increase longevity in various model organisms (Eisenberg et al., 2009; Morselli et al., 2009; Madeo et al., 2010; Marino et al., 2011; Minois et al., 2011; Morselli et al., 2011; Gupta et al., 2013; Minarini et al., 2013). Strategically, increasing Arg1 expression may benefit certain neurodegenerative diseases.

Other strategies have been used to increase Arg1 expression/ activity and downstream product polyamines in an effort to promote neurite and axonal outgrowth in neurons after injury (Cai et al., 2002; Gao et al., 2004; Deng et al., 2009; Ma et al., 2010). In fact, reports show that polyamines bind acidic regions of tubulin, compete with tau through ionic interaction, and promote microtubule assembly (Savarin et al., 2010; Hamon et al., 2011; Lefèvre et al., 2011), suggesting that polyamines support cytoskeletal structure and confer neuronal integrity. Furthermore, poly- amines covalently bind tau (Tucholski et al., 1999) and tubulin (Song et al., 2013) by transglutaminase "polyamination." Although overstabilizing microtubules might also cause neuronal dysfunction, microtubule-stabilizing agents may offer some therapeutic benefit for neurodegenerative disease (Ballatore et al., 2010; Ballatore et al., 2011; Ballatore et al., 2012; Brunden et al., 2012, 2014). This suggests that therapeutic targeting of polyamines through activation of Arg1 could stabilize microtubules, which are destabilized by the failure of phospho-tau to bind the microtubules.

\section{Conclusion}

Overall, our findings imply that arginine metabolism may affect tauopathies. We have shown several potential mechanisms by which sustained Arg1 expression curtails tau pathology. The question remains of whether tau pathology disrupts arginine metabolism and subsequent polyamine homeostasis or if disruption in arginine metabolism promotes tau pathology. Recent evidence shows dyshomeostasis of arginine metabolism and polyamine levels in the brains of AD patients (Liu et al., 2014); however, the functional impact of polyamines on tau during $\mathrm{AD}$ remains elusive. Further research is essential to determine how arginine metabolism and/or polyamine levels contribute to tau pathogenesis, which may offer alternative strategies toward tauopathies.

\section{References}

Angcajas AB, Hirai N, Kaneshiro K, Karim MR, Horii Y, Kubota M, Fujimura S, Kadowaki M (2014) Diversity of amino acid signaling pathways on autophagy regulation: a novel pathway for arginine. Biochem Biophys Res Commun 446:8-14. CrossRef Medline 
A

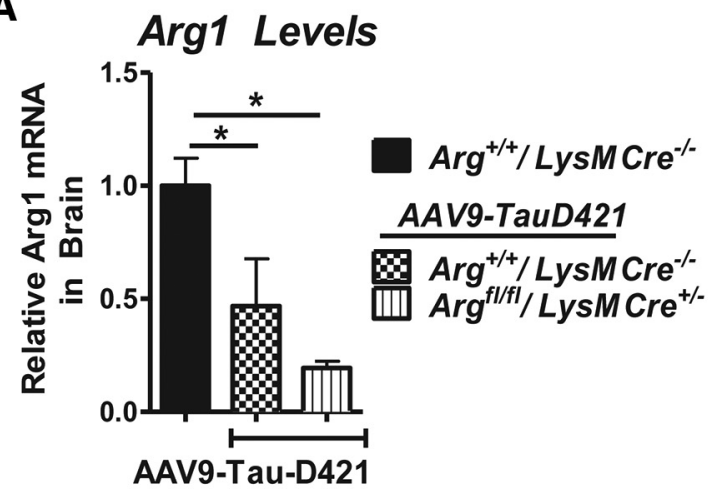

B

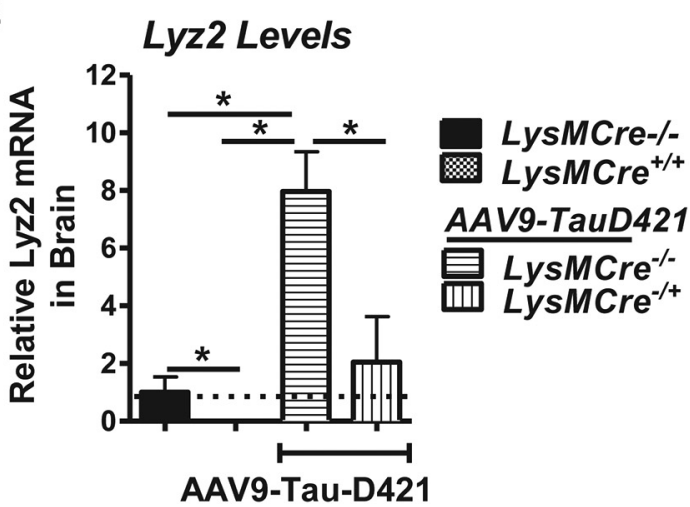

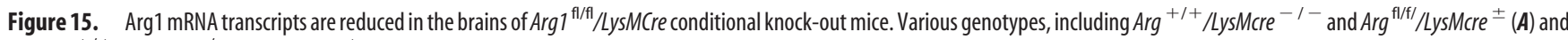
LysMcre $^{+/+}$, LysMcre ${ }^{-/-}$, and LysMcre ${ }^{ \pm}(\boldsymbol{B})$ were tested for the levels of Arg 1 and lysozyme 2 gene (Lyz2) (gene product of LysM promoter) mRNA transcripts in the brains of mice. Homozygous mice for LysMcre produce a knock-out of the Lyz2 gene and thus decreased mRNA transcripts (B). Several genotypes received intrahippocampal injection of an AAV9-C-terminal truncated tau (AAV9-TauCT (D421) viral construct for 4 months. mRNA transcripts for Arg1 and Lyz2 were measured using an RNA standard curve and normalized to Arg1-sufficient mice $\left(\right.$ Arg ${ }^{+/+} / L^{2 y s M c r e}{ }^{-/-}$) for Arg 1 and Lyz2 with wild-type Arg 1 and homozygous alleles for Lyz2. Statistical analyses were performed using ANOVA with Fisher's multiple-comparison test, ${ }^{*} p<0.05 ; n=2-4$.

rAAV-Tau (C-terminal 421)

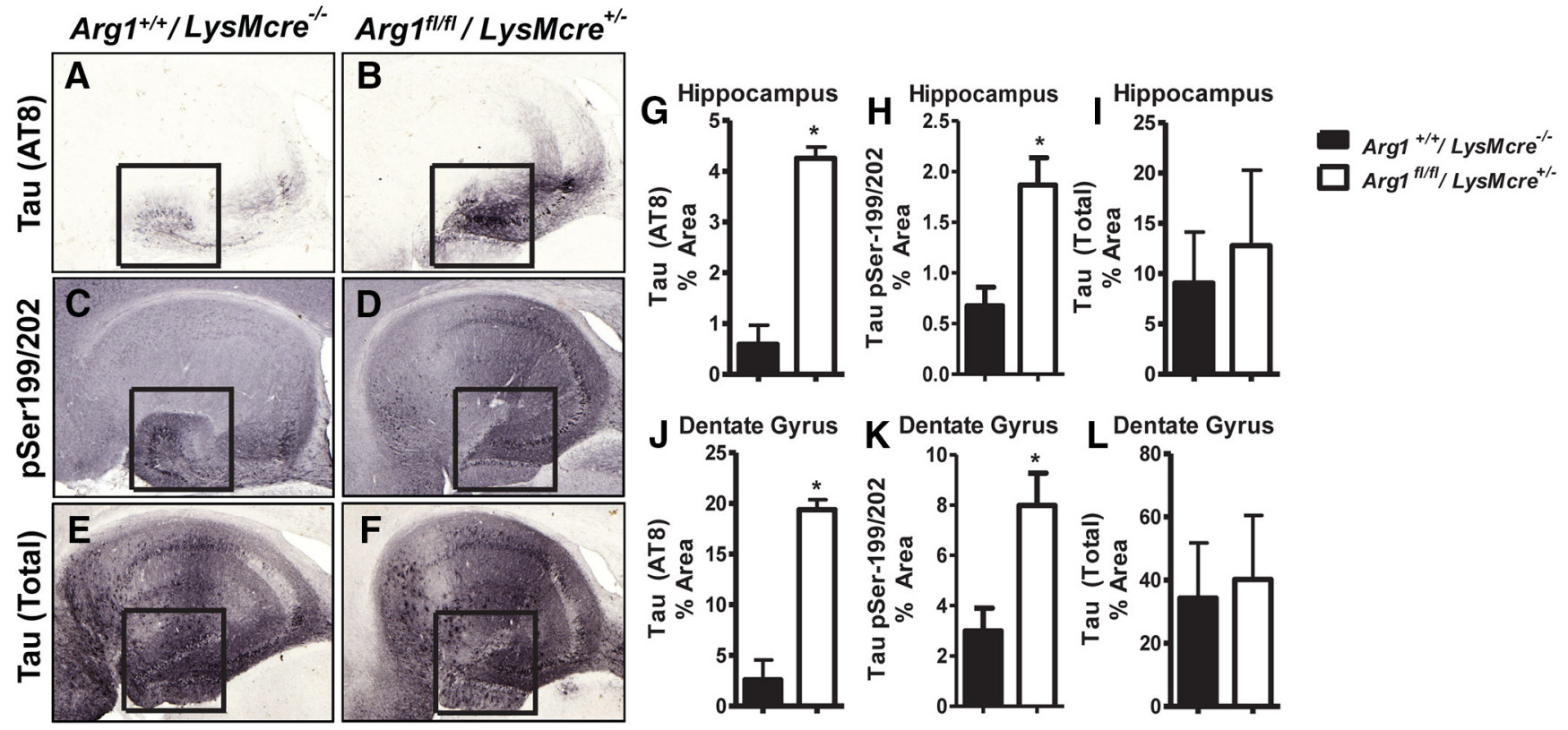

Figure 16. Conditional Arg1-null mice show enhanced phosphor-tau levels after rAAV-mediated C-terminal truncated tau. A C-terminal truncated tau (aa 1-421) construct (rAAV-Tau-CT) was

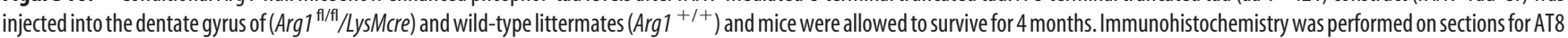
(tau Ser202/Thr205) $(\boldsymbol{A}, \boldsymbol{B})$, tau Ser199/202 (C, D), and total tau $(\boldsymbol{E}, \boldsymbol{F})$. Analysis of the percentage area staining for each group was analyzed for the entire hippocampus $(\boldsymbol{G}-\boldsymbol{I})$ and the dentate gyrus

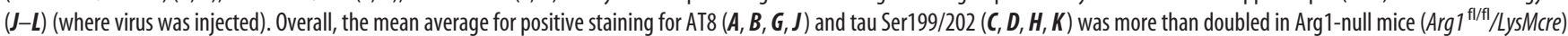
compared with wild-type littermates $\left(\operatorname{Arg} 1^{+/+}\right)$. However, total tau staining was comparable between both Arg1 knock-out mice $\left(\operatorname{Arg} 1^{\text {fl/fl } / L y s M c r e}{ }^{+/+}\right)$and wild-type littermates $\left(\operatorname{Arg} 1^{+/+}\right.$) $(\boldsymbol{E}, \boldsymbol{F}, \boldsymbol{I}, \boldsymbol{L})$. Statistical analyses: two-way ANOVA with Fisher's multiple-comparison as post hoc, ${ }^{*} p<0.05 ; n=3$.

Arnold CS, Johnson GV, Cole RN, Dong DL, Lee M, Hart GW (1996) The microtubule-associated protein tau is extensively modified with O-linked N-acetylglucosamine. J Biol Chem 271:28741-28744. CrossRef Medline Ballatore C, Brunden KR, Piscitelli F, James MJ, Crowe A, Yao Y, Hyde E, Trojanowski JQ, Lee VM, Smith AB 3rd (2010) Discovery of brainpenetrant, orally bioavailable aminothienopyridazine inhibitors of tau aggregation. J Med Chem 53:3739-3747. CrossRef Medline

Ballatore C, Brunden KR, Trojanowski JQ, Lee VM, Smith AB 3rd, Huryn DM (2011) Modulation of protein-protein interactions as a therapeutic strategy for the treatment of neurodegenerative tauopathies. Curr Top Med Chem 11:317-330. CrossRef Medline

Ballatore C, Brunden KR, Huryn DM, Trojanowski JQ, Lee VM, Smith AB 3rd (2012) Microtubule stabilizing agents as potential treatment for Alzheimer's disease and related neurodegenerative tauopathies. J Med Chem 55:8979-8996. CrossRef Medline
Ban H, Shigemitsu K, Yamatsuji T, Haisa M, Nakajo T, Takaoka M, Nobuhisa T, Gunduz M, Tanaka N, Naomoto Y (2004) Arginine and Leucine regulate p70 S6 kinase and 4E-BP1 in intestinal epithelial cells. Int J Mol Med 13:537-543. Medline

Banik S, Renner Viveros P, Seeber F, Klotz C, Ignatius R, Aebischer T (2013) Giardia duodenalis arginine deiminase modulates the phenotype and cytokine secretion of human dendritic cells by depletion of arginine and formation of ammonia. Infect Immun 81:2309-2317. CrossRef Medline

Béchade C, Colasse S, Diana MA, Rouault M, Bessis A (2014) NOS2 expression is restricted to neurons in the healthy brain but is triggered in microglia upon inflammation. Glia 62:956-963. CrossRef Medline

Bhaskar K, Konerth M, Kokiko-Cochran ON, Cardona A, Ransohoff RM, Lamb BT (2010) Regulation of tau pathology by the microglial fractalkine receptor. Neuron 68:19-31. CrossRef Medline

Blair LJ, Nordhues BA, Hill SE, Scaglione KM, O’Leary JC 3rd, Fontaine SN, 
Breydo L, Zhang B, Li P, Wang L, Cotman C, Paulson HL, Muschol M, Uversky VN, Klengel T, Binder EB, Kayed R, Golde TE, Berchtold N, Dickey CA (2013) Accelerated neurodegeneration through chaperonemediated oligomerization of tau. J Clin Invest 123:4158-4169. CrossRef Medline

Brunden KR, Ballatore C, Lee VM, Smith AB 3rd, Trojanowski JQ (2012) Brain-penetrant microtubule-stabilizing compounds as potential therapeutic agents for tauopathies. Biochem Soc Trans 40:661-666. CrossRef Medline

Brunden KR, Trojanowski JQ, Smith AB 3rd, Lee VM, Ballatore C (2014) Microtubule-stabilizing agents as potential therapeutics for neurodegenerative disease. Bioorg Med Chem 22:5040-5049. Medline

Cai D, Deng K, Mellado W, Lee J, Ratan RR, Filbin MT (2002) Arginase I and polyamines act downstream from cyclic AMP in overcoming inhibition of axonal growth MAG and myelin in vitro. Neuron 35:711-719. CrossRef Medline

Carty N, Nash KR, Brownlow M, Cruite D, Wilcock D, Selenica ML, Lee DC, Gordon MN, Morgan D (2013) Intracranial injection of AAV expressing NEP but not IDE reduces amyloid pathology in APP + PS1 transgenic mice. PLoS One 8:e59626. CrossRef Medline

Cho SH, Chen JA, Sayed F, Ward ME, Gao F, Nguyen TA, Krabbe G, Sohn PD, Lo I, Minami S, Devidze N, Zhou Y, Coppola G, Gan L (2015) SIRT1 deficiency in microglia contributes to cognitive decline in aging and neurodegeneration via epigenetic regulation of IL-1beta. J Neurosci 35:807818. CrossRef Medline

Cohen TJ, Guo JL, Hurtado DE, Kwong LK, Mills IP, Trojanowski JQ, Lee VM (2011) The acetylation of tau inhibits its function and promotes pathological tau aggregation. Nat Commun 2:252. CrossRef Medline

Colton CA, Mott RT, Sharpe H, Xu Q, Van Nostrand WE, Vitek MP (2006) Expression profiles for macrophage alternative activation genes in $\mathrm{AD}$ and in mouse models of AD. J Neuroinflammation 3:27. CrossRef Medline

Cripps D, Thomas SN, Jeng Y, Yang F, Davies P, Yang AJ (2006) Alzheimer disease-specific conformation of hyperphosphorylated paired helical filament-Tau is polyubiquitinated through Lys-48, Lys-11, and Lys-6 ubiquitin conjugation. J Biol Chem 281:10825-10838. CrossRef Medline

de Calignon A, Fox LM, Pitstick R, Carlson GA, Bacskai BJ, Spires-Jones TL, Hyman BT (2010) Caspase activation precedes and leads to tangles. Nature 464:1201-1204. CrossRef Medline

Deignan JL, Livesay JC, Yoo PK, Goodman SI, O’Brien WE, Iyer RK, Cederbaum SD, Grody WW (2006) Ornithine deficiency in the arginase double knockout mouse. Mol Genet Metab 89:87-96. CrossRef Medline

Deng K, He H, Qiu J, Lorber B, Bryson JB, Filbin MT (2009) Increased synthesis of spermidine as a result of upregulation of arginase I promotes axonal regeneration in culture and in vivo. J Neurosci 29:9545-9552. CrossRef Medline

DiCarlo G, Wilcock D, Henderson D, Gordon M, Morgan D (2001) Intrahippocampal LPS injections reduce Abeta load in APP + PS1 transgenic mice. Neurobiol Aging 22:1007-1012. CrossRef Medline

Dickey C, Kraft C, Jinwal U, Koren J, Johnson A, Anderson L, Lebson L, Lee D, Dickson D, de Silva R, Binder LI, Morgan D, Lewis J (2009) Aging analysis reveals slowed tau turnover and enhanced stress response in a mouse model of tauopathy. Am J Pathol 174:228-238. CrossRef Medline

Dolan PJ, Johnson GV (2010) A caspase cleaved form of tau is preferentially degraded through the autophagy pathway. J Biol Chem 285:2197821987. CrossRef Medline

Dorval V, Fraser PE (2006) Small ubiquitin-like modifier (SUMO) modification of natively unfolded proteins tau and alpha-synuclein. J Biol Chem 281:9919-9924. CrossRef Medline

Eisenberg T, Knauer H, Schauer A, Büttner S, Ruckenstuhl C, CarmonaGutierrez D, Ring J, Schroeder S, Magnes C, Antonacci L, Fussi H, Deszcz L, Hartl R, Schraml E, Criollo A, Megalou E, Weiskopf D, Laun P, Heeren G, Breitenbach M, et al. (2009) Induction of autophagy by spermidine promotes longevity. Nat Cell Biol 11:1305-1314. CrossRef Medline

El Kasmi KC, Qualls JE, Pesce JT, Smith AM, Thompson RW, Henao-Tamayo M, Basaraba RJ, König T, Schleicher U, Koo MS, Kaplan G, Fitzgerald KA, Tuomanen EI, Orme IM, Kanneganti TD, Bogdan C, Wynn TA, Murray PJ (2008) Toll-like receptor-induced arginase 1 in macrophages thwarts effective immunity against intracellular pathogens. Nat Immunol 9:1399-1406. CrossRef Medline

França-Costa J, Van Weyenbergh J, Boaventura VS, Luz NF, Malta-Santos H, Oliveira MC, Santos de Campos DC, Saldanha AC, dos-Santos WL, Bozza
PT, Barral-Netto M, Barral A, Costa JM, Borges VM (2014) Arginase I, polyamine and prostaglandin E2 pathways suppress the inflammatory response and contribute to diffuse cutaneous leishmaniasis. J Infect Dis 211:426-435. Medline

Gao Y, Deng K, Hou J, Bryson JB, Barco A, Nikulina E, Spencer T, Mellado W, Kandel ER, Filbin MT (2004) Activated CREB is sufficient to overcome inhibitors in myelin and promote spinal axon regeneration in vivo. Neuron 44:609-621. CrossRef Medline

Ghosh S, Wu MD, Shaftel SS, Kyrkanides S, LaFerla FM, Olschowka JA, O’Banion MK (2013) Sustained interleukin-1beta overexpression exacerbates tau pathology despite reduced amyloid burden in an Alzheimer's mouse model. J Neurosci 33:5053-5064. CrossRef Medline

Gordon MN, Holcomb LA, Jantzen PT, DiCarlo G, Wilcock D, Boyett KW, Connor K, Melachrino J, O'Callaghan JP, Morgan D (2002) Time course of the development of Alzheimer-like pathology in the doubly transgenic PS1+APP mouse. Exp Neurol 173:183-195. CrossRef Medline

Gupta VK, Scheunemann L, Eisenberg T, Mertel S, Bhukel A, Koemans TS, Kramer JM, Liu KS, Schroeder S, Stunnenberg HG, Sinner F, Magnes C, Pieber TR, Dipt S, Fiala A, Schenck A, Schwaerzel M, Madeo F, Sigrist SJ (2013) Restoring polyamines protects from age-induced memory impairment in an autophagy-dependent manner. Nat Neurosci 16:14531460. CrossRef Medline

Hamon L, Savarin P, Curmi PA, Pastré D (2011) Rapid assembly and collective behavior of microtubule bundles in the presence of polyamines. Biophys J 101:205-216. CrossRef Medline

Herber DL, Roth LM, Wilson D, Wilson N, Mason JE, Morgan D, Gordon MN (2004) Time-dependent reduction in Abeta levels after intracranial LPS administration in APP transgenic mice. Exp Neurol 190:245-253. CrossRef Medline

Herber DL, Mercer M, Roth LM, Symmonds K, Maloney J, Wilson N, Freeman MJ, Morgan D, Gordon MN (2007) Microglial activation is required for Abeta clearance after intracranial injection of lipopolysaccharide in APP transgenic mice. J Neuroimmune Pharmacol 2:222-231. CrossRef Medline

Hsueh EC, Knebel SM, Lo WH, Leung YC, Cheng PN, Hsueh CT (2012) Deprivation of arginine by recombinant human arginase in prostate cancer cells. J Hematol Oncol 5:17. CrossRef Medline

Jimenez S, Baglietto-Vargas D, Caballero C, Moreno-Gonzalez I, Torres M, Sanchez-Varo R, Ruano D, Vizuete M, Gutierrez A, Vitorica J (2008) Inflammatory response in the hippocampus of PS1M146L/APP751SL mouse model of Alzheimer's disease: age-dependent switch in the microglial phenotype from alternative to classic. J Neurosci 28:11650-11661. CrossRef Medline

Kan MJ, Lee JE, Wilson JG, Everhart AL, Brown CM, Hoofnagle AN, Jansen M, Vitek MP, Gunn MD, Colton CA (2015) Arginine deprivation and immune suppression in a mouse model of Alzheimer's disease. J Neurosci 35:5969-5982. CrossRef Medline

Kettenmann H, Kirchhoff F, Verkhratsky A (2013) Microglia: new roles for the synaptic stripper. Neuron 77:10-18. CrossRef Medline

Kotzbauer PT, Giasson BI, Kravitz AV, Golbe LI, Mark MH, Trojanowski JQ, Lee VM (2004) Fibrillization of alpha-synuclein and tau in familial Parkinson's disease caused by the A53T alpha-synuclein mutation. Exp Neurol 187:279-288. CrossRef Medline

Kummer MP, Hermes M, Delekarte A, Hammerschmidt T, Kumar S, Terwel D, Walter J, Pape HC, König S, Roeber S, Jessen F, Klockgether T, Korte M, Heneka MT (2011) Nitration of tyrosine 10 critically enhances amyloid beta aggregation and plaque formation. Neuron 71:833-844. CrossRef Medline

Kuusisto E, Parkkinen L, Alafuzoff I (2003) Morphogenesis of Lewy bodies: dissimilar incorporation of alpha-synuclein, ubiquitin, and p62. J Neuropathol Exp Neurol 62:1241-1253. Medline

Kyrkanides S, Fiorentino PM, Miller JN, Gan Y, Lai YC, Shaftel SS, Puzas JE, Piancino MG, O’Banion MK, Tallents RH (2007) Amelioration of pain and histopathologic joint abnormalities in the Coll-IL-1beta(XAT) mouse model of arthritis by intraarticular induction of mu-opioid receptor into the temporomandibular joint. Arthritis Rheum 56:2038-2048. CrossRef Medline

Landino LM, Skreslet TE, Alston JA (2004) Cysteine oxidation of tau and microtubule-associated protein- 2 by peroxynitrite: modulation of microtubule assembly kinetics by the thioredoxin reductase system. J Biol Chem 279:35101-35105. CrossRef Medline

Ledesma MD, Bonay P, Colaço C, Avila J (1994) Analysis of microtubule- 
associated protein tau glycation in paired helical filaments. J Biol Chem 269:21614-21619. Medline

Lee DC, Rizer J, Selenica ML, Reid P, Kraft C, Johnson A, Blair L, Gordon MN, Dickey CA, Morgan D (2010) LPS-induced inflammation exacerbates phospho-tau pathology in rTg4510 mice. J Neuroinflammation 7:56. CrossRef Medline

Lee DC, Rizer J, Hunt JB, Selenica ML, Gordon MN, Morgan D (2013a) Review: experimental manipulations of microglia in mouse models of Alzheimer's pathology: activation reduces amyloid but hastens tau pathology. Neuropathol Appl Neurobiol 39:69-85. CrossRef Medline

Lee DC, Ruiz CR, Lebson L, Selenica ML, Rizer J, Hunt JB Jr, Rojiani R, Reid P, Kammath S, Nash K, Dickey CA, Gordon M, Morgan D (2013b) Aging enhances classical activation but mitigates alternative activation in the central nervous system. Neurobiol Aging 34:1610-1620. CrossRef Medline

Lee G, Thangavel R, Sharma VM, Litersky JM, Bhaskar K, Fang SM, Do LH, Andreadis A, Van Hoesen G, Ksiezak-Reding H (2004) Phosphorylation of tau by fyn: implications for Alzheimer's disease. J Neurosci 24:23042312. CrossRef Medline

Lee S, Varvel NH, Konerth ME, Xu G, Cardona AE, Ransohoff RM, Lamb BT (2010) CX3CR1 deficiency alters microglial activation and reduces betaamyloid deposition in two Alzheimer's disease mouse models. Am J Pathol 177:2549-2562. CrossRef Medline

Lee VM, Goedert M, Trojanowski JQ (2001) Neurodegenerative tauopathies. Annu Rev Neurosci 24:1121-1159. CrossRef Medline

Lefèvre J, Chernov KG, Joshi V, Delga S, Toma F, Pastré D, Curmi PA, Savarin P (2011) The C terminus of tubulin, a versatile partner for cationic molecules: binding of Tau, polyamines, and calcium. J Biol Chem 286: 3065-3078. CrossRef Medline

Liu P, Fleete MS, Jing Y, Collie ND, Curtis MA, Waldvogel HJ, Faull RL, Abraham WC, Zhang H (2014) Altered arginine metabolism in Alzheimer's disease brains. Neurobiol Aging 35:1992-2003. CrossRef Medline

Liu Y, Qiang M, Wei Y, He R (2011) A novel molecular mechanism for nitrated \{alpha\}-synuclein-induced cell death. J Mol Cell Biol 3:239-249. CrossRef Medline

Ma TC, Campana A, Lange PS, Lee HH, Banerjee K, Bryson JB, Mahishi L, Alam S, Giger RJ, Barnes S, Morris SM Jr, Willis DE, Twiss JL, Filbin MT, Ratan RR (2010) A large-scale chemical screen for regulators of the arginase 1 promoter identifies the soy isoflavone daidzeinas a clinically approved small molecule that can promote neuronal protection or regeneration via a cAMP-independent pathway. J Neurosci 30:739-748. CrossRef Medline

Madeo F, Eisenberg T, Büttner S, Ruckenstuhl C, Kroemer G (2010) Spermidine: a novel autophagy inducer and longevity elixir. Autophagy 6:160-162. CrossRef Medline

Mantovani A, Sica A, Sozzani S, Allavena P, Vecchi A, Locati M (2004) The chemokine system in diverse forms of macrophage activation and polarization. Trends Immunol 25:677-686. CrossRef Medline

Mariño G, Morselli E, Bennetzen MV, Eisenberg T, Megalou E, Schroeder S, Cabrera S, Bénit P, Rustin P, Criollo A, Kepp O, Galluzzi L, Shen S, Malik SA, Maiuri MC, Horio Y, López-Otín C, Andersen JS, Tavernarakis N, Madeo F, et al. (2011) Longevity-relevant regulation of autophagy at the level of the acetylproteome. Autophagy 7:647-649. CrossRef Medline

Martinez FO, Helming L, Gordon S (2009) Alternative activation of macrophages: an immunologic functional perspective. Annu Rev Immunol 27: 451-483. CrossRef Medline

Minarini A, Zini M, Milelli A, Tumiatti V, Marchetti C, Nicolini B, Falconi M, Farruggia G, Cappadone C, Stefanelli C (2013) Synthetic polyamines activating autophagy: effects on cancer cell death. Eur J Med Chem 67: 359-366. CrossRef Medline

Minois N, Carmona-Gutierrez D, Madeo F (2011) Polyamines in aging and disease. Aging 3:716-732. Medline

Miyamoto A, Wake H, Moorhouse AJ, Nabekura J (2013) Microglia and synapse interactions: fine tuning neural circuits and candidate molecules. Front Cell Neurosci 7:70. Medline

Miyasaka T, Watanabe A, Saito Y, Murayama S, Mann DM, Yamazaki M, Ravid R, Morishima-Kawashima M, Nagashima K, Ihara Y (2005) Visualization of newly deposited tau in neurofibrillary tangles and neuropil threads. J Neuropathol Exp Neurol 64:665-674. CrossRef Medline

Mondragón-Rodríguez S, Basurto-Islas G, Santa-Maria I, Mena R, Binder LI, Avila J, Smith MA, Perry G, García-Sierra F (2008) Cleavage and con- formational changes of tau protein follow phosphorylation during Alzheimer's disease. Int J Exp Pathol 89:81-90. CrossRef Medline

Morris GP, Clark IA, Zinn R, Vissel B (2013) Microglia: a new frontier for synaptic plasticity, learning and memory, and neurodegenerative disease research. Neurobiol Learn Mem 105:40-53. CrossRef Medline

Morselli E, Mariño G, Bennetzen MV, Eisenberg T, Megalou E, Schroeder S, Cabrera S, Bénit P, Rustin P, Criollo A, Kepp O, Galluzzi L, Shen S, Malik SA, Maiuri MC, Horio Y, López-Otín C, Andersen JS, Tavernarakis N, Madeo F, et al. (2011) Spermidine and resveratrol induce autophagy by distinct pathways converging on the acetylproteome. J Cell Biol 192: 615-629. CrossRef Medline

Morselli E, Galluzzi L, Kepp O, Criollo A, Maiuri MC, Tavernarakis N, Madeo F, Kroemer G (2009) Autophagy mediates pharmacological lifespan extension by spermidine and resveratrol. Aging 1:961-970. Medline

Nash KR, Lee DC, Hunt JB Jr, Morganti JM, Selenica ML, Moran P, Reid P, Brownlow M, Guang-Yu Yang C, Savalia M, Gemma C, Bickford PC, Gordon MN, Morgan D (2013) Fractalkine overexpression suppresses tau pathology in a mouse model of tauopathy. Neurobiol Aging 34: 1540-1548. CrossRef Medline

Nolan Y, Maher FO, Martin DS, Clarke RM, Brady MT, Bolton AE, Mills KH, Lynch MA (2005) Role of interleukin-4 in regulation of age-related inflammatory changes in the hippocampus. J Biol Chem 280:9354-9362. CrossRef Medline

Paul S, Kang SC (2013) Natural polyamine inhibits mouse skin inflammation and macrophage activation. Inflamm Res 62:681-688. CrossRef Medline

Peters D, Berger J, Langnaese K, Derst C, Madai VI, Krauss M, Fischer KD, Veh RW, Laube G (2013) Arginase and arginine decarboxylase: where do the putative gate keepers of polyamine synthesis reside in rat brain? PLoS One 8:e66735. CrossRef Medline

Plouffe V, Mohamed NV, Rivest-McGraw J, Bertrand J, Lauzon M, Leclerc N (2012) Hyperphosphorylation and cleavage at D421 enhance tau secretion. PLoS One 7:e36873. CrossRef Medline

Quirié A, Demougeot C, Bertrand N, Mossiat C, Garnier P, Marie C, PrigentTessier A (2013) Effect of stroke on arginase expression and localization in the rat brain. Eur J Neurosci 37:1193-1202. CrossRef Medline

Reyes JF, Reynolds MR, Horowitz PM, Fu Y, Guillozet-Bongaarts AL, Berry R, Binder LI (2008) A possible link between astrocyte activation and tau nitration in Alzheimer's disease. Neurobiology of disease 31:198-208. CrossRef Medline

Reyes JF, Fu Y, Vana L, Kanaan NM, Binder LI (2011) Tyrosine nitration within the proline-rich region of Tau in Alzheimer's disease. Am J Pathol 178:2275-2285. CrossRef Medline

Reyes JF, Geula C, Vana L, Binder LI (2012) Selective tau tyrosine nitration in non-AD tauopathies. Acta Neuropathol 123:119-132. CrossRef Medline

Reynolds MR, Reyes JF, Fu Y, Bigio EH, Guillozet-Bongaarts AL, Berry RW, Binder LI (2006) Tau nitration occurs at tyrosine 29 in the fibrillar lesions of Alzheimer's disease and other tauopathies. J Neurosci 26:1063610645. CrossRef Medline

Rissman RA, Poon WW, Blurton-Jones M, Oddo S, Torp R, Vitek MP, LaFerla FM, Rohn TT, Cotman CW (2004) Caspase-cleavage of tau is an early event in Alzheimer disease tangle pathology. J Clin Invest 114:121130. CrossRef Medline

Ros-Bernal F, Hunot S, Herrero MT, Parnadeau S, Corvol JC, Lu L, AlvarezFischer D, Carrillo-de Sauvage MA, Saurini F, Coussieu C, Kinugawa K, Prigent A, Höglinger G, Hamon M, Tronche F, Hirsch EC, Vyas S (2011) Microglial glucocorticoid receptors play a pivotal role in regulating dopaminergic neurodegeneration in parkinsonism. Proc Natl Acad Sci U S A 108:6632-6637. CrossRef Medline

Sacino AN, Brooks M, McKinney AB, Thomas MA, Shaw G, Golde TE, Giasson BI (2014) Brain injection of alpha-synuclein induces multiple proteinopathies, gliosis, and a neuronal injury marker. J Neurosci 34 12368-12378. CrossRef Medline

Sancak Y, Peterson TR, Shaul YD, Lindquist RA, Thoreen CC, Bar-Peled L, Sabatini DM (2008) The Rag GTPases bind raptor and mediate amino acid signaling to mTORC1. Science 320:1496-1501. CrossRef Medline

Santacruz K, Lewis J, Spires T, Paulson J, Kotilinek L, Ingelsson M, Guimaraes A, DeTure M, Ramsden M, McGowan E, Forster C, Yue M, Orne J, Janus C, Mariash A, Kuskowski M, Hyman B, Hutton M, Ashe KH (2005) Tau suppression in a neurodegenerative mouse model improves memory function. Science 309:476-481. CrossRef Medline 
Savaraj N, You M, Wu C, Wangpaichitr M, Kuo MT, Feun LG (2010) Arginine deprivation, autophagy, apoptosis (AAA) for the treatment of melanoma. Curr Mol Med 10:405-412. CrossRef Medline

Savarin P, Barbet A, Delga S, Joshi V, Hamon L, Lefèvre J, Nakib S, De Bandt JP, Moinard C, Curmi PA, Pastré D (2010) A central role for polyamines in microtubule assembly in cells. Biochem J 430:151-159. CrossRef Medline

Scalabrino G, Ferioli ME (1984) Polyamines in mammalian ageing: an oncological problem, too? A review. Mech Ageing Dev 26:149-164. CrossRef Medline

Sengupta U, Guerrero-Munoz MJ, Castillo-Carranza DL, Lasagna-Reeves CA, Gerson JE, Paulucci-Holthauzen AA, Krishnamurthy S, Farhed M, Jackson GR, Kayed R (2015) Pathological interface between oligomeric alpha-synuclein and tau in synucleinopathies. Biol Psychiatry. In press.

Shaftel SS, Kyrkanides S, Olschowka JA, Miller JN, Johnson RE, O’Banion MK (2007) Sustained hippocampal IL-1 beta overexpression mediates chronic neuroinflammation and ameliorates Alzheimer plaque pathology. J Clin Invest 117:1595-1604. CrossRef Medline

Shin TM, Isas JM, Hsieh CL, Kayed R, Glabe CG, Langen R, Chen J (2008) Formation of soluble amyloid oligomers and amyloid fibrils by the multifunctional protein vitronectin. Mol Neurodegener 3:16. CrossRef Medline

Song Y, Kirkpatrick LL, Schilling AB, Helseth DL, Chabot N, Keillor JW, Johnson GV, Brady ST (2013) Transglutaminase and polyamination of tubulin: posttranslational modification for stabilizing axonal microtubules. Neuron 78:109-123. CrossRef Medline

Tucholski J, Kuret J, Johnson GV (1999) Tau is modified by tissue transglutaminase in situ: possible functional and metabolic effects of polyamination. J Neurochem 73:1871-1880. Medline

Varin A, Gordon S (2009) Alternative activation of macrophages: immune function and cellular biology. Immunobiology 214:630-641. CrossRef Medline

Wake H, Moorhouse AJ, Miyamoto A, Nabekura J (2013) Microglia: actively surveying and shaping neuronal circuit structure and function. Trends Neurosci 36:209-217. CrossRef Medline

Wang JZ, Gao X, Wang ZH (2014) The physiology and pathology of microtubule-associated protein tau. Essays Biochem 56:111-123. CrossRef Medline

Weisser SB, Kozicky LK, Brugger HK, Ngoh EN, Cheung B, Jen R, Menzies SC, Samarakoon A, Murray PJ, Lim CJ, Johnson P, Boucher JL, van Rooijen N, Sly LM (2014) Arginase activity in alternatively activated macrophages protects PI3Kp110delta deficient mice from dextran sodium sulfate-induced intestinal inflammation. Eur J Immunol 44:3353-3367. CrossRef Medline

Welch JS, Escoubet-Lozach L, Sykes DB, Liddiard K, Greaves DR, Glass CK (2002) TH2 cytokines and allergic challenge induce Ym1 expression in macrophages by a STAT6-dependent mechanism. J Biol Chem 277: 42821-42829. CrossRef Medline

Wu FL, Liang YF, Chang YC, Yo HH, Wei MF, Shen LJ (2011) RNA interference of argininosuccinate synthetase restores sensitivity to recombinant arginine deiminase (rADI) in resistant cancer cells. J Biomed Sci 18:25. CrossRef Medline

Wullschleger S, Loewith R, Hall MN (2006) TOR signaling in growth and metabolism. Cell 124:471-484. CrossRef Medline

Yao K, Yin YL, Chu W, Liu Z, Deng D, Li T, Huang R, Zhang J, Tan B, Wang W, Wu G (2008) Dietary arginine supplementation increases mTOR signaling activity in skeletal muscle of neonatal pigs. J Nutr 138:867-872. Medline

Yu H, Iyer RK, Kern RM, Rodriguez WI, Grody WW, Cederbaum SD (2001) Expression of arginase isozymes in mouse brain. J Neurosci Res 66 : 406-422. CrossRef Medline

Yu H, Iyer RK, Yoo PK, Kern RM, Grody WW, Cederbaum SD (2002) Arginase expression in mouse embryonic development. Mech Dev 115(1-2):151-155.

Yu H, Yoo PK, Aguirre CC, Tsoa RW, Kern RM, Grody WW, Cederbaum SD, Iyer RK (2003) Widespread expression of arginase I in mouse tissues: biochemical and physiological implications. J Histochem Cytochem 51: 1151-1160. CrossRef Medline

Yu Z, Xu X, Xiang Z, Zhou J, Zhang Z, Hu C, He C (2010) Nitrated alphasynuclein induces the loss of dopaminergic neurons in the substantia nigra of rats. PLoS One 5:e9956. CrossRef Medline 